RECEIVED

APR 011996

OSTI

\title{
GUIDANCE FOR IMPLEMENTING THE LONG-TERM SURVEILLANCE Program For UMTRA PROJECT TITLE I DISPOSAL SITES
}

February 1996

This report was prepared as an account of work sponsored by an agency of the United States Government. Neither the United States Government nor any agency thereof, nor any of their employees, makes any warranty, express or implied, or assumes any legal liability or responsibility for the accuracy, completeness, or usefulness of any information, apparatus, product, or process disclosed, or represents that its use would not infringe privately owned rights. Reference herein to any specific commercial product, process, or service by trade name, trademark, manufacturer, or otherwise does not necessarily constitute or imply its endorsement, recommendation, or favoring by the United States Government or any agency thereof. The views and opinions of authors expressed herein do not necessarily state or reflect those of the United States Government or any agency thereof. 
This report has been feptoducedifitom the best available copy. Available in paper copy and microfiche

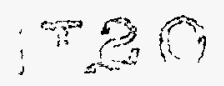

Number of pages in this report: 76

DOE and DOE contractors can obtain copies of this report from:

Office of Scientific and Technical Information

P.O. Box 62

Oak Ridge, TN 37831

(615) 576-8401

This report is publicly available from:

Nàtional Technical Information Service

Department of Commerce

5285 Port Royal Road

Springfield, VA 22161

(703) $487-4650$

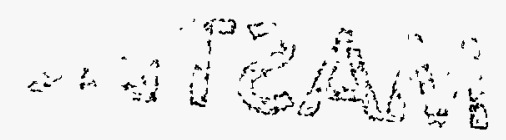


This document supersedes document number UMTRA-DOE/AL-350125.0000 (Rev. 1)

Prepared for

U.S. Department of Energy Environmental Restoration Division UMTRA Project Team

Albuquerque, New Mexico

Prepared by Jacobs Engineering Group Inc. Albuquerque, New Mexico 

TABLE OF CONTENTS

Section

Page

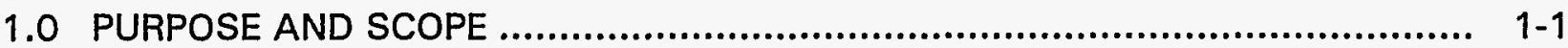

2.0 LONG-TERM SURVEILLANCE PLAN................................................. $2-1$

2.1 Purpose and scope of site-specific LTSPs ....................................... $2-1$

2.2 Legal site description................................................................. $2-1$

2.3 Final disposal site conditions ..................................................... $2-2$

2.3.1 Processing history and associated contaminants ....................... 2-2

2.3.2 Description and location of the disposal site area ........................ 2-3

2.3.3 Disposal cell design .............................................................. 2-6

2.3.4 Disposal site drawings and photographs................................... 2-7

2.4 Long-term surveillance program description........................................ $2-7$

2.4.1 Site inspections, scope, and frequency .............................. $2-7$

2.4 .2 Follow-up inspections...................................................... 2-11

2.4.3 Ground water monitoring .................................................. 2-11

2.4.4 Custodial maintenance or repair ......................................... 2 2-12

2.4.5 Corrective action ........................................................... 2-13

2.4.6 Record keeping ................................................................ 2-14

2.4.7 Emergency notification and reporting ..................................... 2-15

2.4.8 Quality assurance ..................................................... 2-15

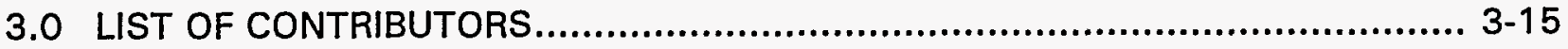

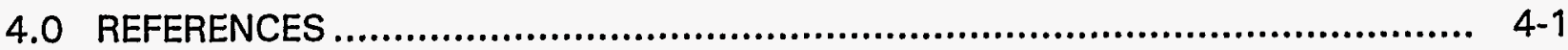

ATTACHMENT 1 U.S. NUCLEAR REGULATORY COMMISSION REGULATIONS (10 CFR $\$ 40.27$ )

ATTACHMENT 2 SAMPLES OF PERMANENT SITE SURVEILLANCE FEATURES

ATTACHMENT 3 SAMPLE INSPECTION CHECKLIST

ATTACHMENT 4 DISPOSAL SITE AND DISPOSAL CELL INSPECTION TECHNIQUES

ATTACHMENT 5 EARTHQUAKE REPORTING CRITERIA 


\section{LIST OF TABLES}

Table

Page

2.1 Maximum concentration of constituents for ground water protection ............... 2-5

2.2 UMTRA Project disposal site key holders ............................................... $2-9$ 


\section{LIST OF ACRONYMS}

$\begin{array}{ll}\text { Acronym } & \text { Definition } \\ \text { DOE } & \text { U.S. Department of Energy } \\ \text { LTSP } & \text { long-term surveillance plan } \\ \text { MCL } & \text { maximum concentration limit } \\ \text { NRC } & \text { U.S. Nuclear Regulatory Commission } \\ \text { RAP } & \text { remedial action plan } \\ \text { UMTRA } & \text { Uranium Mill Tailings Remedial Action } \\ \text { UMTRCA } & \text { Uranium Mill Tailings Radiation Control Act }\end{array}$




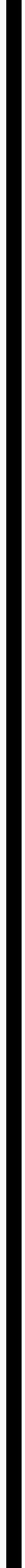




\subsection{PURPOSE AND SCOPE}

This guidance document has two purposes: it provides guidance for writing site-specific long-term surveillance plans (LTSP) and it describes site surveillance, monitoring, and longterm care techniques for Title I disposal sites of the Uranium Mill Tailings Radiation Control Act (UMTRCA) (42 USC $\$ 7901$ et seq.). Long-term care includes monitoring, maintenance, and emergency measures needed to protect public health and safety and the environment after remedial action is completed.

This document applies to the UMTRCA-designated Title I disposal sites. The requirements for long-term care of the Title I sites and the contents of the LTSPS are provided in U.S. Nuclear Regulatory Commission (NRC) regulations (10 CFR \$40.27) provided in Attachment 1. 



\subsection{LONG-TERM SURVEILLANCE PLAN}

The NRC regulations (10 CFR \$40.27) require that each LTSP include descriptions of the disposal site and disposal cell, final disposal site conditions, and the surveillance program; and criteria for follow-up inspections and instituting maintenance.

LTSPS may reference information in documents previously submitted to the NRC, specifying when reference to site-specific documentation is appropriate (10 CFR $\$ 40.27(b)$ ).

\subsection{PURPOSE AND SCOPE OF SITE-SPECIFIC LTSPS}

An LTSP must state its purpose and scope. Its purpose is first, to comply with NRC regulatory requirements (10 CFR \$40.27) during and after the licensing process and second, to facilitate the long-term care of the disposal cell. The LTSP also describes baseline conditions for comparisons over time. Its scope is limited to the disposal site.

\subsection{LEGAL SITE DESCRIPTION}

The LTSP must include a legal description of the disposal site as required by 10 CFR $\$ 40.27(b)(1)$.

The site description contains the number of acres included in the site. It also includes the type of real estate instruments associated with conveying the site from the affected state to the United States or with the negotiation of a custodial agreement between the U.S. Department of Energy (DOE) and tribes.

Documents containing information associated with the land transaction le.g., book, page, county, state, and date for deeds; Federal Register number and date for transfer of jurisdiction; and agreement number and date associated with tribal agreements) should be listed in the LTSP, with the following statement:

Real estate correspondence and instruments are maintained and filed by the Property Management Branch and Administrative Services Property Division, Albuquerque Operations Office (phone number).

The document also states that copies of all real estate documents will be maintained in the permanent site files.

A surveyor's description of the property as recorded and filed at the county seat (or equivalent office) is attached to the LTSP. It includes the township, range, and section (nearest quarter section) or equivalent system (e.g., metes and bounds). 


\subsection{FINAL DISPOSAL SITE CONDITIONS}

An LTSP summarizes final disposal site conditions, as a baseline for comparisons over time. The comparisons are made during cell performance monitoring described in Section 2.4 below. The site-specific remedial action plan (RAP), as-builts, and completion report should be summarized and referenced for more details.

The LTSP also summarizes the final disposal site description, ground water conditions, and all planned ground water protection activities as required by 10 CFR $\$ 40.27(b)(2)$. This description (in the LTSP or a referenced document) must be detailed enough that inspectors can determine changes from baseline conditions and determine when these changes require maintenance or repairs.

\subsubsection{Processing history and associated contaminants}

The LTSP also summarizes historical information related to surface and ground water (e.g., years of operation, processes, and volume of material processed), and references other site documents for more processing details so the quantity and quality of the tailings stabilized in the cell are understood by the regulators and inspectors.

\section{Hazardous constituents in stabilized tailings}

An LTSP identifies constituents with established maximum concentration limits (MCL), other hazardous constituents listed in Appendix I of 40 CFR Part 192, and hazardous constituents of concern that are present in or reasonably derived from the tailings stabilized in the disposal cell.

For most sites, hazardous constituents are identified (in the site RAP) by sampling and analyzing tailings pore water and by subsequent ground water characterization. In addition to chemical analysis of tailings pore fluids, the LTSP summarizes other factors that could result in constituents being added to or removed from the list of hazardous constituents proposed in the RAP. These factors include, but are not limited to the following:

- The chemical composition of the raw ore.

- Chemical agents used for uranium extraction.

- Chemical analysis data from sampling collection ponds, subsurface soils, or contaminated ground water at the processing site.

- The chemical properties of Appendix I (40 CFR Part 192) compounds when they come into contact with water (e.g., stability and solubility). 
The LTSP also discusses other water quality parameters of the disposal site environment that may explain or predict potential contaminant migration. Pore water data and other data used to characterize the disposal material may be summarized in a table that also summarizes background and/or on-site contaminant concentrations.

\subsubsection{Description and location of the disposal site area}

The as-built and current descriptions of the disposal site area in the LTSP should include the following information:

- A figure locating the disposal site within the region (e.g., state, county, nearby towns, highways, major waterways).

- A road log or figure with instructions for traveling to the site.

- Land use, surface and ground water use, and land ownership of the surrounding areas.

- Surface features of the disposal site including topography, drainage patterns, natural or cultural resources, surface waters, and physiographic setting.

- Vegetation on and around the cell at completion as well as a current description of any volunteer plant growth.

- Subsurface features including ground water characterization.

- Climate including average annual precipitation, temperature and evaporation, prominent wind direction, and vegetation.

If ground water monitoring is to be done, the LTSP summarizes Uranium Mill Tailings Remedial Action (UMTRA) Project ground water monitor well data in the disposal cell vicinity if the wells 1 ) are specifically referenced in the text, 2) will be used in future ground water protection activities at the disposal site, or 3) are not planned for sampling but will remain at the disposal site after licensing. A table could list the monitoring locations and provide relevant information for each location, such as formation of completion and depth of screened interval. Springs or seeps that are used for monitoring should be summarized. A site map should show monitoring locations used for background characterization.

In the context of the LTSP, background ground water quality represents the quality that would exist in the uppermost aquifer at the disposal site if neither the tailings disposal nor any previous uranium processing at the disposal site had occurred. The LTSP summarizes and updates the RAP discussion on background ground water quality in the uppermost aquifer with respect to the basic properties of background ground water: 
- Total dissolved solids.

- Major cations (e.g., sodium, magnesium, calcium) and anions (e.g., sulfate, chloride, bicarbonate).

- $\mathrm{pH}$.

- Oxidation-reduction potential.

- Trace elements and constituents exceeding MCLs (Table 2.1).

- Range or variability in background water quality.

- Comparison to regional data, if available.

If the ground water protection strategy is based on a supplemental standard related to background ground water quality, the LTSP summarizes the basis for that determination.

It is important to note that some disposal cells are located on former uranium processing sites, where milling operations typically had introduced processingrelated contaminants into the ground water. The presence of preexisting ground water contamination in the vicinity of the disposal cell complicates efforts to assess disposal cell performance by direct monitoring of ground water quality downgradient of the disposal cell. When the same contaminants contained in the disposal material are already present in the ground water under the disposal cell, future concentrations of preexisting contamination are difficult to predict.

An LTSP does not discuss potential changes in water quality due to failure of the disposal cell. An LTSP does summarize anticipated or reasonably possible changes in ground water conditions in the monitored aquifer at the disposal site and may discuss changes in ground water quality caused by the following:

- Impacts from disposal cell construction or drainage of the excess water from the disposal cell.

- Natural flushing or active remediation of existing ground water contamination at the site.

- Future land or water uses in the vicinity of the site.

- Short-term precipitation effects, cyclical seasonal variation, or long-term climatic influence. 
Table 2.1 Maximum concentration of constituents for ground water protection

\begin{tabular}{|c|c|}
\hline Constituent & Maximum concentration $^{a}$ \\
\hline Arsenic & 0.05 \\
\hline Barium & 1.0 \\
\hline Cadmium & 0.01 \\
\hline Chromium & 0.05 \\
\hline Lead & 0.05 \\
\hline Mercury & 0.002 \\
\hline Selenium & 0.01 \\
\hline Silver & 0.05 \\
\hline Nitrate (as N) & 10 \\
\hline Molybdenum & 0.1 \\
\hline Combined radium-226 and radium-228 & $5 \mathrm{pCi} / \mathrm{L}$ \\
\hline Combined uranium-234 and uranium- $238^{\mathrm{b}}$ & $30 \mathrm{pCi} / \mathrm{L}$ \\
\hline Gross alpha-particle activity (excluding radon and uranium) & $15 \mathrm{pCi} / \mathrm{L}$ \\
\hline $\begin{array}{l}\text { Endrin }(1,2,3,4,10,10 \text {-hexachloro-6,7-exposy-1,4,4a,5,6,7,8,8a- } \\
\text { octahydro-1,4-endo,endo-5,8-dimethanonaphthalene) }\end{array}$ & 0.0002 \\
\hline Lindane $(1,2,3,4,5,6$-hexachlorocyclohexane, gamma insomer) & 0.004 \\
\hline Methoxychlor (1,1,1-trichloro-2,2'-bis(p-methoxyphenylethane)) & 0.1 \\
\hline $\begin{array}{l}\text { Toxaphene }\left(\mathrm{C}_{10} \mathrm{H}_{10} \mathrm{Cl}_{6} \text {, technical chlorinated camphene, 67-69 }\right. \\
\text { percent chlorine) }\end{array}$ & 0.005 \\
\hline 2,4-D (2,4-dichlorophenoxyacetic acid) & 0.1 \\
\hline 2,4,5-TP Silvex (2,4,5-trichlorophenoxypropionic acid) & 0.01 \\
\hline
\end{tabular}

${ }^{a}$ Milligrams per liter, unless stated otherwise.

${ }^{b}$ Where secular equilibrium obtains, this criterion will be satisfied by a concentration of 0.044 milligrams per liter $(\mathrm{mg} / \mathrm{L})$. For conditions other than secular equilibrium, a corresponding value may be derived and applied, based on the measured site-specific ratio of the two isotopes of uranium.

From Table 1 of 40 CFR Part 192, Subpart A.

$\mathrm{pCi} / \mathrm{L}$ - picocuries per liter. 


\subsubsection{Disposal cell design}

The LTSP summarizes cell design and performance expectations and references appropriate sections of site-specific documents, including the RAP and completion report, for more information.

UMTRA Project disposal cells are designed to be effective for 1000 years or at least 200 years, with no more than custodial maintenance

(40 CFR \$192.02(a)(d)). An LTSP should summarize the following:

- Major constructed components of the disposal cell, including dimensions.

- A plan view and cross sections of the disposal cell.

- The cover system (i.e., rock or vegetative) drainage controls, and other features that contribute to cell performance.

- Design elements necessary for ground water protection.

- Other performance features (e.g., compaction densities, frost protection, infiltration, and cover drainage).

- The locations, coordinates, types, numbers, and figures of permanent site surveillance features including survey monuments, boundary monuments, site markers, entrance and perimeter signs, settlement plates, etc.

Examples are provided in Attachment 2.

Field observations show that rock covers on UMTRA Project disposal cells support volunteer plant growth (DOE, 1992a; Burt, 1995). Although this plant growth was not planned, it was acknowledged early in the UMTRA Project that some limited plant growth likely would occur on the cells (DOE, 1985). The common plant species growing on many of the disposal cells are known and should be described or referenced in the LTSP. The LTSP also should summarize or specify the locations of the following information:

- Status of volunteer plant growth on the cell when the LTSP is written.

- Information (including field data) regarding the rooting patterns of some of the common plants observed on the rock-covered disposal cells (DOE, 1992a; Burt, 1995), and data from the literature pertaining to rooting patterns of some common species observed at the sites (DOE, 1995).

- Vegetation control measures used at the site.

- Future conditions that may dictate the initiation or continued use of vegetation control measures. 


\subsubsection{Disposal site drawings and photographs}

The LTSP states that all drawings, maps, and photographs are archived in the permanent site files and are accessible for review prior to site inspections. This information illustrates baseline conditions against which future conditions at the disposal site can be compared. As-built drawings, baseline photographs, and aerial photographs are included in the descriptions of disposal site as-built conditions at the completion of remedial action. The permanent site file contains vicinity maps, a topographic map, a disposal site map, and photographs of the site. The site file is updated when necessary, and after each site inspection.

\section{$2.4 \quad$ LONG-TERM SURVEILLANCE PROGRAM DESCRIPTION}

The LTSP describes the long-term surveillance program: inspection frequency, reporting to NRC, inspection personnel qualifications, inspection procedures, frequency and extent of ground water monitoring (if required), appropriate constituent concentration limits for ground water, record keeping, and quality assurance procedures (10 CFR $\$ 40.27(\mathrm{~b})(3))$. The LTSP refers to the cooperative agreements between the DOE and the tribes and states for direction on notifying and reporting to the tribe or state.

\subsubsection{Site inspections, scope, and frequency}

The LTSP describes disposal site inspections. The objectives of the site inspection are to report on the condition of the disposal cell, note any changes or modifications to the disposal cell and disposal site over time, and identify potential problems. The LTSP should state that all activities will be conducted in compliance with DOE-approved personnel health and safety programs. The inspection detects and documents progressive changes over several years as a result of slow-acting, natural processes. Comparing baseline conditions recorded in the completion report to inspection findings provides a basis for determining cell performance.

After an inspection, a site inspection report is prepared and the permanent site file is updated. The inspection report is submitted by DOE to the NRC within 90 days of the inspection.

An inspection is conducted at least annually at each disposal site, as is stated in the LTSP and required by 10 CFR $\$ 40.27(b)(3)$.

\section{Inspection team}

The LTSP recommends the minimal requirements for the site inspection team, including the requirements for the minimum number of inspectors and the need for technical specialists on the team based on the disposal site design, specific site surveillance requirements, conditions expected at the site, and amount of time needed to complete the inspection. A minimum of two inspectors 
comprise an inspection team. Team members should have the technical background and/or experience needed to evaluate on-site physical conditions.

\section{Preparing for and conducting an inspection}

The LTSP refers to this guidance document for recommendations on inspection preparation and conduct. Prior to conducting inspections, inspectors should:

- Review the RAP, completion report, as-builts, and other appropriate documents listed in the bibliography attached to the LTSP.

- Review the LTSP, the permanent site file, previous site inspection reports, site inspection maps, and any maintenance or corrective action reports.

- Verify and update the names and telephone numbers of all parties with whom access or notification agreements have been executed.

- Verify the DOE 24-hour telephone number and appropriate tribal/state agency telephone numbers and contacts. Arrange to change the entrance sign, as needed.

- Notify NRC of the inspection.

- Notify off-site parties and obtain permission to enter adjacent property, if necessary.

- Adjust the Brunton compass's magnetic declination for the specific disposal site region. All azimuths or bearings should be oriented to true north for each disposal site.

During an inspection, site inspectors must:

- Observe the condition of all permanent features and anomalous or unexpected features that may require closer inspection (e.g., erosion features such as gullies or rills, sediment accumulations, vandalism, animal intrusion, plant growth).

- Record observations in field notebooks and on site maps.

- Complete a site inspection checklist (Attachment 3).

- Take and log photographs to document conditions at the disposal site and to provide a continuous record for monitoring changing conditions over time. 


\section{Disposal site access and security}

The LTSP describes or refers to 1) DOE agreements with area landowners or state or local agencies for permanent access to the disposal site (road rights-ofway), and for access to and use of areas outside the disposal site boundary to conduct ground water monitoring, if needed; and 2) how the DOE inspects off-site features identified for long-term surveillance. If Privacy Act requirements preclude the inclusion of some of this information in an LTSP, the location of the information is referenced.

The LTSP also identifies the need for prior notification or permission to access the site from non-DOE property, and for special provisions that may be needed to access the disposal site (e.g., obtaining keys to locked gates) (Table 2.2).

Table 2.2 UMTRA Project disposal site key holders

\begin{tabular}{ccl}
\hline \multicolumn{1}{c}{ Title and current contact } & \multicolumn{1}{c}{ Telephone } & \multicolumn{1}{c}{ Address } \\
\hline DOE UMTRA Project Site Manager & (505) 845-4022 & $\begin{array}{l}\text { U.S. Department of Energy } \\
\text { Environmental Restoration Division } \\
\text { UMTRA Project Team }\end{array}$ \\
& & 2155 Louisiana NE, Suite 4000 \\
& & Albuquerque, NM 87110 \\
& & 2597 B 3/4 Road \\
GJPO UMTRA Project Engineer & (970) 248-6006 & \\
& &
\end{tabular}

\section{Inspection checklist}

An inspection checklist that addresses site-specific conditions should be developed and updated for each site. Prior to annual inspections, the previous inspection checklist should be reviewed and updated as needed. The checklist addresses site-specific conditions and requirements, including:

- Specific features to be inspected and photographed. For example, the area within approximately 0.25 miles (mi) $(0.40$ kilometer $[\mathrm{km}])$ of the center of the disposal site; evidence of human, plant, or animal activity; or geomorphic features (e.g., stream channels or gullies) that could initiate significant erosion.

- Unique cell design criteria requiring monitoring.

- Quantifiable data needing recording.

- Volunteer plant growth requiring identification and measurement. 
- Stream length. If a disposal site is near a stream, or on the floodplain or a terrace of a stream, the stream length within $0.25 \mathrm{mi}(0.40 \mathrm{~km})$ of the site center should be traversed to evaluate whether the stream poses any threat to the site.

- High water levels or new high water marks, areas of active erosion and sedimentation, and changes in channel position.

The checklist should be revised as needed to include new information or to delete items that are no longer pertinent.

\section{Disposal site and disposal cell inspection}

The LTSP refers to Attachment 4 of this guidance document for minimal and prudent disposal site and disposal cell inspection procedures that should be considered during planning for site inspections.

\section{Inspection reporting requirements}

An LTSP specifies inspection reporting requirements. The site inspection report must include the following information at a minimum:

- Data and location of inspection.

- Narrative of site inspection, results, conclusions, and recommendations.

- Site inspection checklist and any relevant supporting documentation.

- Site inspection map and other drawings, maps, or figures, as required.

- Inspection photographs and photo log sheet.

- Recommendations for follow-up inspections, repair, or custodial maintenance.

- Custodial maintenance or repair report and certification.

- Description and quantification of a problem requiring corrective action.

- Status of ongoing or incomplete custodial maintenance or corrective action.

- Conclusions and recommendations.

- Names, qualifications, and signatures of inspectors.

The regulations (10 CFR $\$ 40.27(b)(3)$ ) require the DOE to submit the results of all site inspections to the NRC within 90 days of the site inspection unless 
unusual damage or disruption is discovered. Then the site investigation report must be submitted within 60 days per 10 CFR $\$ 40.27(b)(3)$. A copy of all site inspection reports will be maintained in the permanent site file.

\subsubsection{Follow-up inspections}

The NRC regulations require that the criteria for follow-up inspections in response to observations from routine inspections and extreme natural events must be included in the LTSP (10 CFR $\$ 40.27(\mathrm{~b})(4))$. The NRC is notified prior to the follow-up inspection if the reported problem indicates the disposal cell has been compromised or that extensive repair or corrective action could be needed. Follow-up inspections will be conducted by technical specialists in the disciplines appropriate to the problem that has been reported.

Follow-up inspection reports may include:

- A description of the problem that triggered the follow-up inspection.

- A preliminary assessment of the maintenance, repair, or corrective action required.

- Conclusions and recommendations.

- Assessment data, including field and inspection data, and photographs.

- Inspectors names, qualifications, and signatures.

\subsubsection{Ground water monitoring}

The NRC regulations require that each LTSP describe the proposed frequency and extent of ground water monitoring, and appropriate constituent concentration limits for ground water (10 CFR $\$ 40.27$ (b)(3)). However, the LTSP must state when and why the ground water monitoring is not planned for a site.

An LTSP does not describe compliance activities for preexisting ground water contamination associated with uranium milling activities unless these activities could impact the ground water protection strategy of the disposal cell or the ability to assess these strategies. If so, they are summarized in the LTSP.

\section{Disposal sites not requiring ground water monitoring}

If ground water monitoring is not necessary at a disposal site, the rationale for no monitoring is summarized in the LTSP. This summary consists of the minimum description of the ground water characteristics needed to support the summary. It references appropriate documents for more information on ground 
water characteristics and the justification for not performing ground water monitoring at or near the site.

\section{Disposal sites requiring best management practices}

Although some sites may not require ground water monitoring, specific areas at or near these sites may need limited monitoring. Best management practices are developed for those situations. The ground water description is summarized from the RAP, with additional information provided if special circumstances require limited monitoring. The RAP also is referenced for more information on ground water characteristics and the justification for not monitoring ground water at or near the site. The LTSP also references other site-specific documents that justify limited monitoring.

\section{Disposal sites requiring ground water monitoring}

The water sampling and analysis plan for each site should be summarized or referenced in the LTSP. Ground water samples will be collected in compliance with the most recent DOE-approved standard operating procedures. The LTSP will specify the frequency, extent, and locations of ground water sampling.

Ground water monitoring data should be analyzed to determine if the cell is functioning as designed. Analytical methods are described in technical documents prepared for the UMTRA Project.

\subsubsection{Custodial maintenance or repair}

The LTSP identifies routine or reasonably anticipated custodial activities, the timing and frequency with which they are performed, and the manner in which the work is authorized (10 CFR $\$ 40.27(b)(5)$ ). The following examples of maintenance or repair may be specified.

- Planned maintenance: grass mowing, road maintenance, removal of weeds or debris, vegetation control, or replacement of entrance sign.

- Unscheduled maintenance: removal of deep-rooted or other unwanted vegetation, or removal of animal burrows on the disposal cell.

- Repair: damage to disposal cell, fence, gate or locks, surveillance features, wells or roads.

Failure of planned vegetation to establish within a specified amount of time may also require repair.

The LTSP also describes custodial care certification and reporting requirements. At a minimum, the party that performs the work provides DOE with verification of the work. DOE inspects the work and certifies that it was completed in 
accordance with the specifications. Documentation of the custodial maintenance or repair is included in the annual report to the NRC.

A record of the custodial work documented and incorporated in the permanent site file includes:

- Summary of work required.

- Work order, purchase order, or statement of work.

- Contractor qualifications.

- Contractor documentation of completion of work.

- DOE certification of completion of work.

\subsubsection{Corrective action}

The difference between a repair and a corrective action is subjective and will require periodic discussion between DOE and NRC. Unanticipated problems could affect the disposal cell's ability to remain in compliance with the EPA standards. The need for corrective action is determined by the cause and magnitude of the problem, the immediate threat to the public or the environment, and the need to comply with applicable standards. The criteria for instituting corrective measures is stated in the LTSP (10 CFR $\$ 40.27(b)(5))$.

The site inspectors evaluate the problem and make recommendations for the next step (e.g., immediate action or continued evaluation). After the NRC reviews the report and its recommendations, the DOE prepares a corrective action plan and submits it to the NRC. Corrective action begins after the NRC has reviewed the plan.

NRC regulations do not specify a time frame for implementing corrective action. However, the EPA ground water standards require that a corrective action program must be in operation no later than 18 months after a finding of exceedance (40 CFR \$192.04). Assessing the extent of the problem and developing a corrective action plan is not considered initiation of the corrective action program.

The following examples of UMTRA Project disposal site conditions may require corrective action:

- Surface rupture of the disposal cell, such as cracks with dimensions considered a potential breach to the integrity of the cell, indications of differential settlement, or severe shrinkage of the cover materials.

- Subsidence, sliding, or slope instability on the disposal cell (caused by mass wasting, liquefaction, differential settlement, or other events).

- Development of rills or gullies considered an actual or potential breach to cell integrity. 
- Volunteer plant growth root systems that could compromise cover system integrity.

- Deterioration of the erosion protection rock on the disposal cell or in the drainage ditches.

- Seepage originating from the disposal cell or the toe of the cell.

- Development of gullies on or adjacent to disposal site property that could affect the integrity of the disposal cell.

- Rapid headward cutting of a nearby gully, arroyo, or ravine that threatens the stability of the disposal cell.

- Encroachment of stream channels onto the disposal site.

- Damage to the cell cover or disposal site property because of river encroachment, seismic events, flooding, catastrophic events, volunteer plant growth, or vandalism (removal of cell construction materials).

- Ground water quality degradation.

The LTSP discusses certification of corrective action and the reporting requirements for the progress of the corrective action. The NRC reviews the progress reports, which may be appended to the site inspection and/or annual report. After the corrective action is completed, all work is certified by the DOE in accordance with the design specifications and in accordance with EPA standards. The NRC reviews the certification that the corrective action is acceptable. All reports, data, and documentation generated during the corrective action, including a copy of the certification statement, are retained in the permanent site file.

\subsubsection{Record keeping}

The LTSP identifies and summarizes the DOE-approved record keeping requirements that apply to LTSP documentation. DOE updates and maintain the following documents:

- The DOE's annual report to the NRC documenting the results of the inspections as required by 10 CFR $\$ 40.27(\mathrm{~b})(3)$.

- Files and original deeds, custody agreements, and other property documents.

- Surveillance and maintenance documentation. 
- Corrective action records.

- Other documents deemed important by DOE.

Original site inspection documentation and records are kept for a minimum of 5 years; the site inspection reports will be kept for a minimum of 10 years. At the end of the specified holding period, all records, reports, and other documentation will be copied on microfiche (or its equivalent) for permanent storage in DOE archives. All information is available for review by the NRC and the public.

\subsubsection{Emergency notification and reporting}

An LTSP includes copies of agency agreements and emergency and reporting procedures (e.g., the DOE agreements with the U.S. Geological Survey National Earthquake Information Service and the National Weather Service to notify the DOE in the event of an earthquake, a tornado, or flooding in the disposal site area). Attachment 5 provides the criteria for earthquake reporting requirements.

The LTSP states that if a site-related emergency requires public notification, the DOE takes appropriate action to notify individuals who may be affected and advise them of precautions that should be taken. Local law enforcement officials, news media, DOE and NRC representatives, and tribal or state representatives are included in this process. Nothing in the LTSP may negate or override DOE occurrence reporting requirements.

The designated facility contact telephone number also is posted on the site entrance sign (DOE 24-hour number), allowing area residents to contact the DOE when problems are discovered. Annual updates (the DOE telephone number, contact lists, and telephone numbers for all agencies and parties with whom the DOE has a contractual arrangement) are conducted in conjunction with the site inspection.

\subsubsection{Quality assurance}

The LTSP refers to DOE quality assurance requirements that must be followed during implementation of the surveillance and maintenance program, including DOE Order 5700.6C, Quality Assurance, and the Long-Term Surveillance Program Quality Assurance Program Plan (DOE, 1992b). 

GUIDANCE FOR IMPLEMENTING THE LONG-TERM SURVEILLANCE

PROGRAM FOR UMTRA PROJECT TITLE I DISPOSAL SITES

LIST OF CONTRIBUTORS

3.0 LIST OF CONTRIBUTORS

The following individuals contributed to the preparation of this guidance document.

\begin{tabular}{ll}
\hline Name & Contribution \\
\hline $\begin{array}{l}\text { M. Gawthrop-Cooper, J. Gibb, } \\
\text { D. Berley, R. Keri Zagal, }\end{array}$ & Senior technical review \\
M. Hansen, J. Lommler, R. Saar, & \\
A. Holm & \\
M. Gawthrop-Cooper & Document coordinator, authorship \\
P. Martinez & Real estate \\
J. Torline, J. Jones & Technical editing \\
L. Sanchez, WordCenter, Inc. & Word processing \\
\hline
\end{tabular}

DOE/AL/62350-189

REV, 0 , YER, 6

19-Feb-96

1060653.DOC (DOC)

3-1 


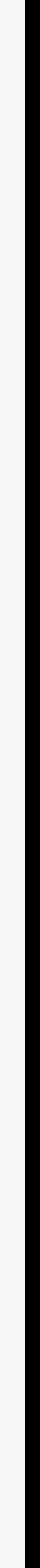




\subsection{REFERENCES}

Burt, C., 1995. Jacobs Engineering Group Inc., personal communication with S. Cox, Jacobs Engineering Group Inc., UPDCC File Location No. 5.15.1.1, Albuquerque, New Mexico, 5 October 1995.

DOE (U.S. Department of Energy), 1995. UMTRA Project Disposal Cell Cover Biointrusion Sensitivity Assessment, DOE/AL/62350-200, Rev. 1, prepared for the U.S. Department of Energy, Environmental Restoration Division, UMTRA Project Team, Albuquerque, New Mexico.

DOE (U.S. Department of Energy), 1992a. Vegetation Growth Patterns on Six RockCovered UMTRA Project Disposal Cells, DOE/AL-400677.0000, prepared for the U.S. Department of Energy, UMTRA Project Office, Albuquerque Operations Office, Albuquerque, New Mexico.

DOE (U.S. Department of Energy), 1992b. Long-Term Surveillance and Maintenance Program Quality Assurance Program Plan, P-GJPO-152, July 1992, prepared for the U.S. Department of Energy by Chem Nuclear Geotech, Inc., DOE Grand Junction Projects Office, Grand Junction, Colorado.

DOE (U.S. Department of Energy), 1985. Technical Summary of the UMTRA Project Technology Development Program (1980-1984), UMTRA-DOE/AL200125.0000, prepared for the U.S. Department of Energy, UMTRA Project Office, Albuquerque Operations Office, Albuquerque, New Mexico.

EPA (U.S. Environmental Protection Agency), 1992. Addendum to Interim Final Guidance, Statistical Analysis of Ground-Water Monitoring Data at RCRA Facilities, Office of Solid Waste Management Division, U.S. Environmental Protection Agency, Washington, D.C.

\section{CODE OF FEDERAL REGULATIONS}

10 CFR Part 40, Domestic Licensing of Source Material, U.S. Nuclear Regulatory Commission.

40 CFR Part 192, Health and Environmental Protection Standards for Uranium and Thorium Mill Tailings, U.S. Environmental Protection Agency.

\section{DOE ORDERS}

Order 5700.6C, Quality Assurance, August 21, 1991, Office of Nuclear Energy, Washington, D.C. 


\section{UNITED STATES CODE}

42 USC $\$ 7901$ et seq., Uranium Mill Tailings Radiation Control Act of 1978, November 8, 1978. 
ATTACHMENT 1

U.S NUCLEAR REGULATORY COMMISSION REGULATIONS

(10 CFR §40.27) 


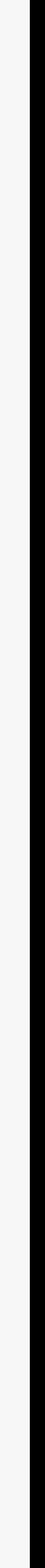


flce listed in appendix $D$ of part 20 of this chapter, the name and address of the person recelving the source material pursuant to such transfer.

(e) Ang person recelving, acquiring, possessing, using, or transferring depleted uranium pursuant to the general ifcense established by paragraph (a) of this section is exempt from the requirements of parts 19,20 and 21 of this chapter with respect to the depleted uranium covered by that general Hcense.

[11 FR 53331, Dec. 6, 1976, as amended at 42 FR 28896, June 6, 1977; 43 FR 623, Feb. 17, 1978; 43 FR 52202, No7. 9, 1978; 52 FR 31611, Aus. 21, 1987]

840.26 General license for possession and storage of byproduct material as defined in this part.

(a) A general license is hereby issued to recelve title to, own, or possess byproduct material as defined in this part without regard to form or quantity.

(b) The general license in paragraph (a) of this section applies only: In the case of licensees of the Commission, where activities that result in the production of byproduct material are authorized under a speciffc license issued by the Commission pursuant to this part, to byproduct material possessed or stored at an authorized disposal containment area or transported incident to such authorized activity: Provided, That authority to recelve title to, own, or possess byproduct material under this general license shall terminate when the specific license for source material expires, is renewed, or is amended to include a specific license for byproduct material as defined in this part.

(c) The general license in paragraph (a) of this section is subject to:

(1) The provisions of parts $19,20,21$, and $\$ \$ 40.1,40.2 a, 40.3,40.4,40.5,40.6$, $40.41,40.46,40.60,40.61,40.62,40.63,40.65$, 40.71 , and 40.81 of part 40 of this chapter; and

(2) The documentation of daily inspections of taillings or waste retention 8ystems and the immediate notiffertion of the appropriate NRC regional office as indicated in appendix $D$ to 10 CFR part 20 of this chapter, or the Director, Offlce of Nuclear Material Safety and Safeguards, U.S. Nuclear Regu- latory Commission, Washington, DC 20555, of any fallure in a tailings or waste retention system that results in a release of tailings or waste into unrestricted areas, or of any unusual conditions (conditions not contemplated in the design of the retention system) that if not corrected could lead to fallure of the system and result in a release of tailings or waste into unrestricted areas; and any additional requirements the Commission may by order deem necessary. The licenseo shall retain this documentetion of each daily inspection as a record for three years after each inspection is documented.

(d) The general Hcense in peragraph (a) of this section shall expire nine months from the effective date of this subparagraph unless an applicable licensee has submitted, pursuant to the provisions of $\$ 40.31$ of this part, an application for license renewal or amendment which includes a detailed program for meeting the technical and flnancial criteria contained in appendix $A$ of this part.

[44 FR 50014, Aug. 24, 1979, as amended at 45 FR 12277, Feb. 26, 1980; $45 \mathrm{FR} 65531$, Oct. 3, 1980; 53 FR 19248, May 27, 1988; 56 FR 40768, Aug. 16, 1991]

\section{$\$ 40.27$ General license for custody and long-term care of residual radio- active material disposal site.}

(a) A general license is issued for the custody of and long-term care, including monitoring, maintenance, and emergency measures necessary to protect public health and safety and other actions necessary to comply with the standards promulgated under section 275(a) of the Atomic Energy Act of 1954, as amended, for disposal sites under title I of the Uranium Mill Tailings Radiation Control Act of 1978, as amended. The license is available only to the Department of Energy, or another Federal agency designated by the President to provide long-term care. The purpose of this general license is to ensure that uranium mill tallings disposal sites will be cared for in such a manner as to protect the public health, safety, and the environment after remedial action has been completed.

(b) The general license in paragraph (a) of this section becomes effective 
when the Commission accepts a site Long-Term Surveillance Plan (LTSP) that meets the requirements of this section, and when the Commission concurs with the Department of Energy's determination of completion of remedial action at each disposal site. There is no termination of this general 11cense. The LTSP may incorporate by reference information contained in documents prevlously submitted to the Commission if the references to the individual incorporated documents are clear and specific. Each LTSP must include-

(1) A legal description of the disposal site to be licensed, including documentation on whether land and interests are owned by the United States or an Indian tribe. If the site is on Indian land, then, as specifled in the Uranium Mill Tailings Radiation Control Act of 1978, as amended, the Indian tribe and any person holding any interest in the land shall execute a waiver releasing the United States of any liability or claim by the Tribe or person concerning or arising from the remedial action and holding the United States harmless against any claim arising out of the performance of the remedial action;

(2) A detalled description, which can be in the form of a reference, of the final disposal site conditions, including existing ground water characterization and any necessary ground water protection activities or strategies. This description must be detailed enough so that future inspectors will have a baseline to determine changes to the site and when these changes are serious enough to require maintenance or repairs. If the disposal site has continuing aquifer restoration requirements, then the licensing process will be completed in two steps. The first step includes all items other than ground water restoration. Ground water monitoring, which would be addressed in the ITSP, may still be required in this first step to assess performance of the tailings disposal units. When the Commission concurs with the completion of ground water restoration, the licensee shall assess the need to modify the ITSP and report results to the commission. If the proposed modifications meet the requirements of this section, the ITSP will be considered suitable to accommodate the second step.

(3) A description of the long-term surveillance program, including proposed inspection frequency and reporting to the Commission (as specifled in appendix $A$, criterion 12 of this part), frequency and extent of ground water monitoring if required, approprlate constituent concentration limits for ground water, inspection personnel qualifications, inspection procedures, recordkeeping and quality assurance procedures;

(4) The criteria for follow-up inspections in response to observations from routine inspections or extreme natural events; and

(5) The criteria for instituting maintenance or emergency measures.

(c) The long-term care agency under the general license established by paraBraph (a) of this section shall-

(1) Implement the ITSP as described in paragraph (b) of this section;

(2) Care for the disposal site in accordance with the provisions of the ITSP;

(3) Notify the Commission of any changes to the ITSP; the changes may not conflict with the requirements of this section;

(4) Guarantee permanent right-ofentry to Cormmission representatives for the purpose of periodic site inspections; and

(5) Notify the Commission prior to undertaking any significant construction, actions, or repairs related to the disposal site, even if the action is required by a state or another Federal agency.

(d) As specified in the Uranium Mill Tailings Radiation Control Act of 1978. as amended, the Secretary of the Interior, with the concurrence of the Secretary of Energy and the Commission, may sell or lease any subsurface mineral rights associated with land on which residual radioactive materials are disposed. In such cases, the Commission shall grant a license permitting use of the land if it finds that the use will not disturb the residual radioactive materials or that the residual radionctive materials will be restored to a safe and environmentally sound condition if they are disturbed by the use. 
(e) The general license in paragraph (a) of this section is exempt from parts 19,20 , and 21 of this chapter, unless significant construction, actions, or repairs are required. If these types of actions are to be undertaken, the licensee shall explain to the Commission which requirements from these parts apply for the actions and comply with the appropriate requirements.

[55 FR 45598, Oct. 30, 1990]

80.28 General license for custody and long-term care of nanium or thorium byproduct materials disposal sites.

(a) A general license is issued for the custody of and long-term care, including monitoring, maintenance, and emergency measures necessary to protect the public health and safety and other actions necessary to comply with the standards in this part for uranium or thorium mill tailings sites closed under title II of the Uranium Mill Tailings Radiation Control Act of 1978, as amended. The licensee will be the Department of Energy, another Federal agency designated by the President, or a State where the disposal site is 10cated. The purpose of this general ifcense is to ensure that uranium and thorfum mill tailings disposal sites will be cared for in such a manner as to protect the public health, safety, and the environment after closure.

(b) The general license in paragraph (a) of this section becomes effective when the Commission terminates, or concurs in an Agreement State's termination of, the current specific license and a site Long-Term Surveillance Plan (LTSP) meeting the requirements of this section has been accepted by the Commission. There is no termination of this general license. If the LTSP has not been formally received by the NRC prior to termination of the current specific license, the Commission may issue a specific order to the intended custodial agency to ensure continued control and survelllance of the disposal site to protect the public health, safety, and the environment. The Commission will not unnecessarily delay the termination of the speciffc license soleis on the basis that an acceptable LTSP has not been received. The LTSP may incorporate by reference informa- tion contained in documents previously submitted to the Commission if the references to the individual incorporated documents are clear and spocific. Each ITSP must includo-

(1) A legal description of the disposal site to be transferred (unless transfer is exempted under provisions of the Atomic Energy Act, $\$ 83(\mathrm{~b})(1)(A)$ ) and licensed;

(2) A detailed description, which can be in the form of a reference of the final disposal site conditions, including existing ground water characterization. This description must be detalled enough so that future inspectors will have a baseline to determine changes to the site and when these changes are serious enough to require maintenance or repairs;

(3) A description of the long-term surveillance program, including proposed inspection frequency and reporting to the Commission (as specifled in appendix A, Criterion 12 of this part), frequency and extent of ground water monitoring if required, appropriate constituent concentration limits for ground water, inspection personnel qualifications, inspection procedures, recordkeeping and quality assurance procedures;

(4) The criteria for follow-up inspections in response to observations from routine inspections or extreme natural events; and

(5) The criteria for instituting maintenance or emergency measures.

(c) The long-term care agency who has a general license established by paragraph (a) of this section shall-

(1) Implement the ITSP as described in paragraph (b) of this section;

(2) Care for the disposal site in accordance with the provisions of the ITSP;

(3) Notify the Commission of any changes to the LTSP; the changes may not conflict with the requirements of this section;

(4) Guarantee permanent right-ofentry to Commission representatives for the purpose of periodic site inspections; and

(5) Notify the Commission prior to undertaking any significant construction, actions, or repairs related to the disposal site, even if the action is re- 
safety, welfare, or enfronment, the Com mission may permit the use of the surface or subsurface estates, or both, of such land in a manner consistent with the provisions provided in these criteria. If the Commission permits such use of such land, it will provide the person who transferred such land with the right of first refusal with respect to such use of such land.

E. Material and land transferred to the United States or a State in accordance with this Criterion must be transferred without cost to the United States or a State other than administrative and legal costs incurred in carrying out such transfer.

F. The provislons of this part respecting transfer of title and custody to land and tallings and wastes do not apply in the case of lands held in trust by the United States for any Indlan tribe or lands owned by such Indian tribe subject to a restriction egrinst allenation imposed by the United States. In the case of such lands which are used for the disposal of byproduct material, as defined in this Part, the licensee shall enter into arrangements with the Commission as may be appropriate to assure the long-term survelllance of such lands by the United States.

\section{Long-Term Site Surveillance}

Criterion 12-The final disposition of tailings, residual radioactive material, or wastes at milling sites should be such that ongolng active malntenance is not necessary to preserve isolation. As a minimum, annual site Inspections must be conducted by the government agency responsible for longterm care of the disposal site to confirm its integrity and to determine the need, if any. for maintenance and/or monitoring. Results of the inspections for all the sites under the licensee's jurisdiction will be reported to the Commission annually within 90 days of the last site inspection in that calendar year. Any site where unusual damage or disruption is discovered during the inspection, however, will require a preliminary site inspection report to be submitted within 60 days. On the basis of a site specific evaluation, the Commission may require more frequent site inspections if necessary due to the features of a particular disposal site. In this case, a preliminary inspection report is required to be submitted within 60 days following each inspection.

\section{Hazardous Constituents}

Criterion 13-Secondary ground-water protection standards required by Criterion 5 of this appendix are concentration limits for individual hazardous constituents. The following list of constituents identifies the constituents for which standards must be set and complied with if the specific constituent is reasonably expected to be in or derived from the byproduct material and has been detected in sround water. For purposes of this appendix, the property of Bross alpha activity will bo treated as if it is a hazardous constituent. Thus, when setting standards under paragraph $5 \mathrm{~B}(5)$ of Criterion 5 , the Commission will also set a limit for eross alpha activity. 'The Commission does not consider the following list imposed by 40 CFR Part 192 to be exhaustive and may dotermine other constituents to be hezardous on a case-by-case basis, independent of those specified by the U.S. Environmental Protection Agency in Part 192

\section{HAZARDOUS CONBTHUUATS}

Acetonitrile (Ethanenitrile)

Acetophenone (Ethanone, 1-phenyl)

3-(alpha-Acetonylbenzyl)-A-hydroxy coumarin and salts (Warfarin)

2-Acetylaminonuorene (Acetamide, N-(9Hfluoren-2-yl)-)

Acetyl chloride (Ethanoyl chlorlde)

1-Acetyl-2-thiourea (Acetamide,

(aminothioxomethyl)-)

Acrolein (2-Propenal)

Acrylamide (2-Propenamide)

Acrylonitrile (2-Propenenitrile)

Allatoxins

Aldorin

$(1,2,3,4,10,10$-Hexachloro-

$1,4,48,5,8,8 \mathrm{a}, 8 \mathrm{~b}$-hexahydro-endo, exo-1,4:5,8Dimethanonaphthalene)

Allyl alcohol (2-Propen-1-ol)

Aluminum phosphide

4-Aminobiphenyl ([1,1'-Biphenyl]-4-amine)

6-Amino-1,18,2,8,88,8b-hexahydro-8-

(hydroxymethyl)-8a-methoxy-5-methyl-

carbamate azirino[2; $\left.3^{\prime}: 3,4\right]$ pyrro $]$ [1,2-

a]indole-4,7-dione, (ester) (Mitomycin C)

- (Azirfno[2'3':3,4]pyrrolo(1,2-8)indole-4,7-

dione, 6-amino-8-[((amino-

cabonyl)oxy)methyl]-1,1a,2,8,8a,8b-hexa-

hydro-8a methoxy-5-methy-)

5-(Aminomethy 1)-3-isozazolol

Aminopyridine (4-Pyridinamine)

Amitrole (1F-1,2,4-Triazol-3-amine)

Aniline (Benzenamine)

Antimony and compounds, N.O.S. ${ }^{3}$

Aramite (Sulfurous acid, 2-chloroethyl-, 2-[4(1,1-dimethylethyl)

methylethyl ester)

Arsenic and compounds, N.O.S.3

Arsenic acid (Orthoarsenic acid)

Arsenic pentoxide (Arsenic (V) oxide)

Arsenic trioxide (Arsenic (III) oxide)

Auramine (Benzenamine, carbonimidoylbis[N,N-Dimethylmonohydrochloride)

Azaserine (L-Serine, diazoacetate (ester))

Barium and compounds, N.O.S.3

Barium cyanide

3The abbreviation N.O.S. (not otherrise specified) signifies those members of the general class not specifically listed by name in this list. 


\section{ATTACHMENT 2}

SAMPLES OF PERMANENT

SITE SURVEILLANCE FEATURES 


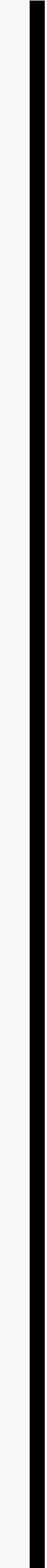




\section{LIST OF FIGURES}

Figure

Page

A2.1 Example disposal site survey monument

A2.2 Example disposal site boundary monument

A2.3 Example disposal site marker

A2-3

A2.4 Example disposal site marker message

A2-4

A2.5 Example disposal site warning sign

\section{LIST OF TABLES}

Table

Page

A2.1 Example locations of disposal site permanent surveillance features............. A2-6 
. 
Figure 4.1

Survey Monument

Gunnison, Colorado, Site
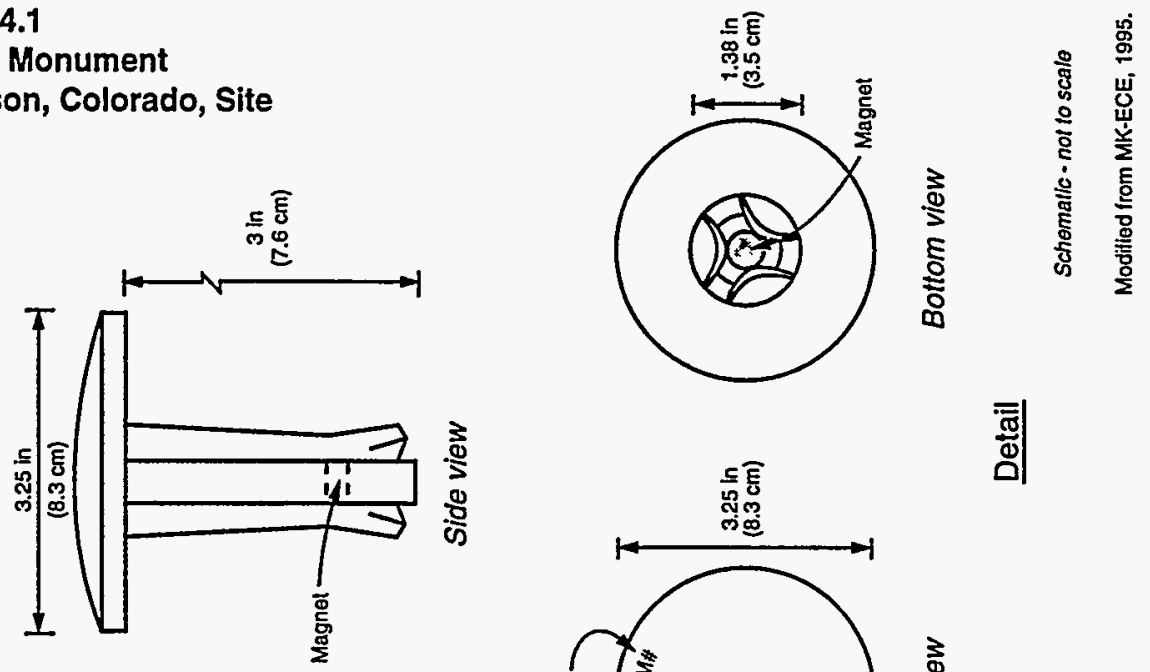

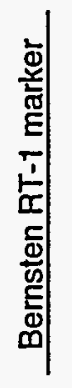

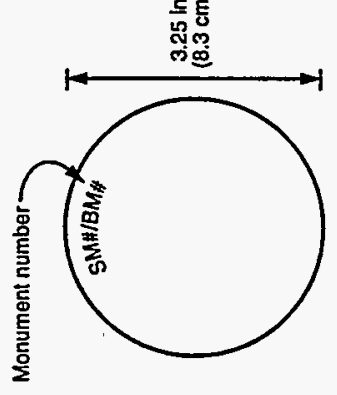

$\frac{3}{9}$
$\stackrel{5}{5}$
$\frac{8}{2}$
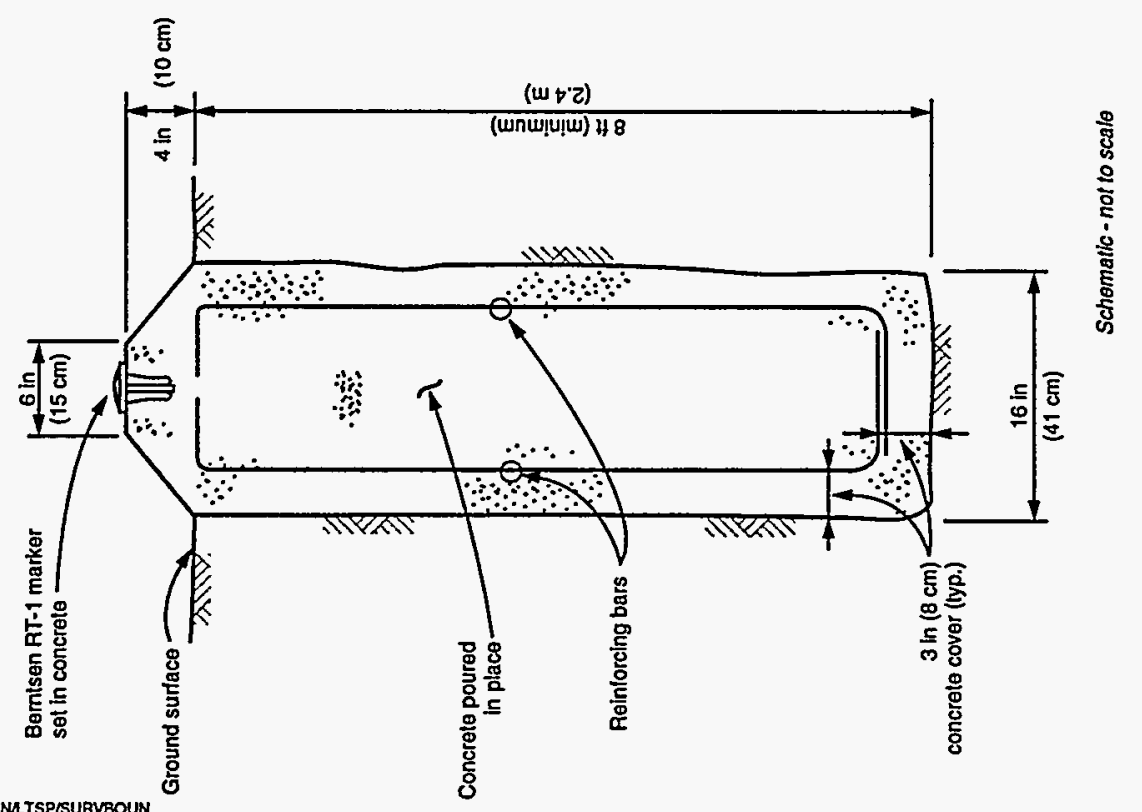

A2.1 Example disposal site survey monument 
Figure 4.2

Boundary Monument

Gunnison, Colorado, Site
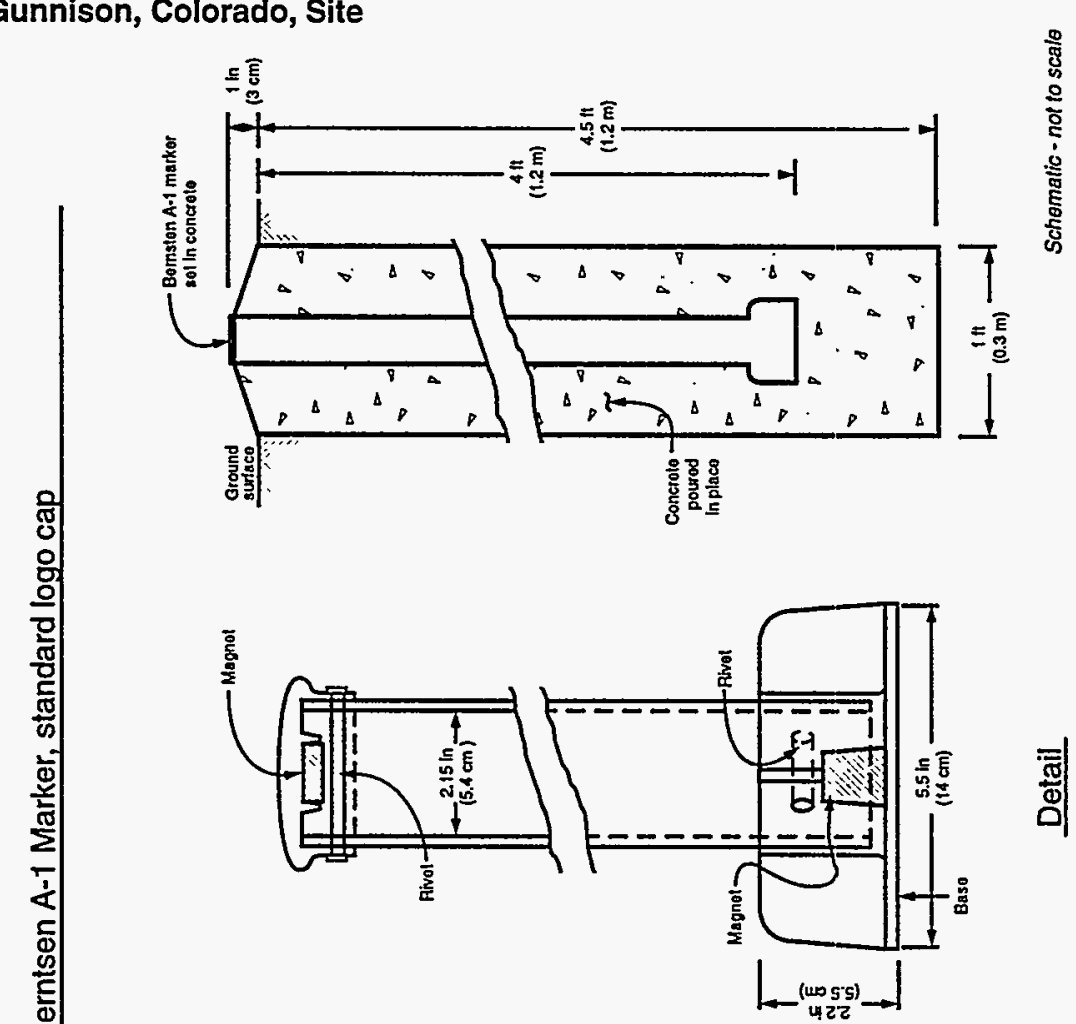

ฐ্ฐ

MAC: STEEGUMLTSPBOUNMON

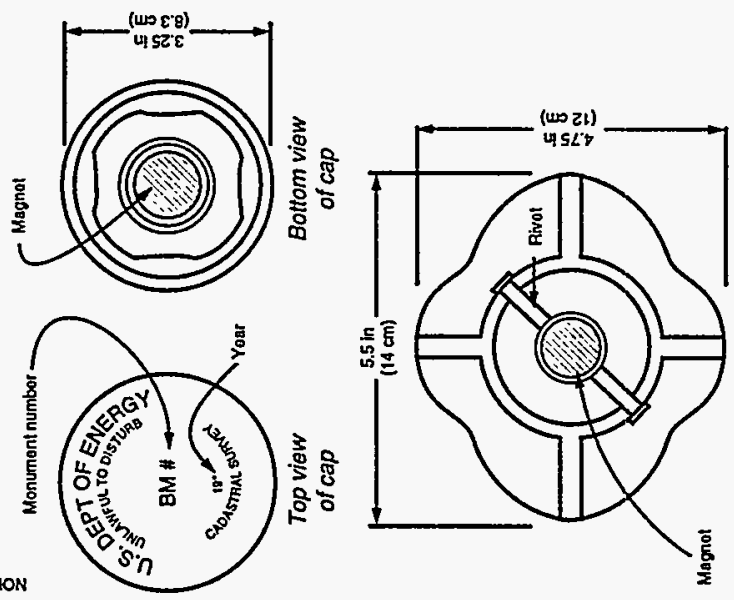

总

A2.2 Example disposal site boundary monument 


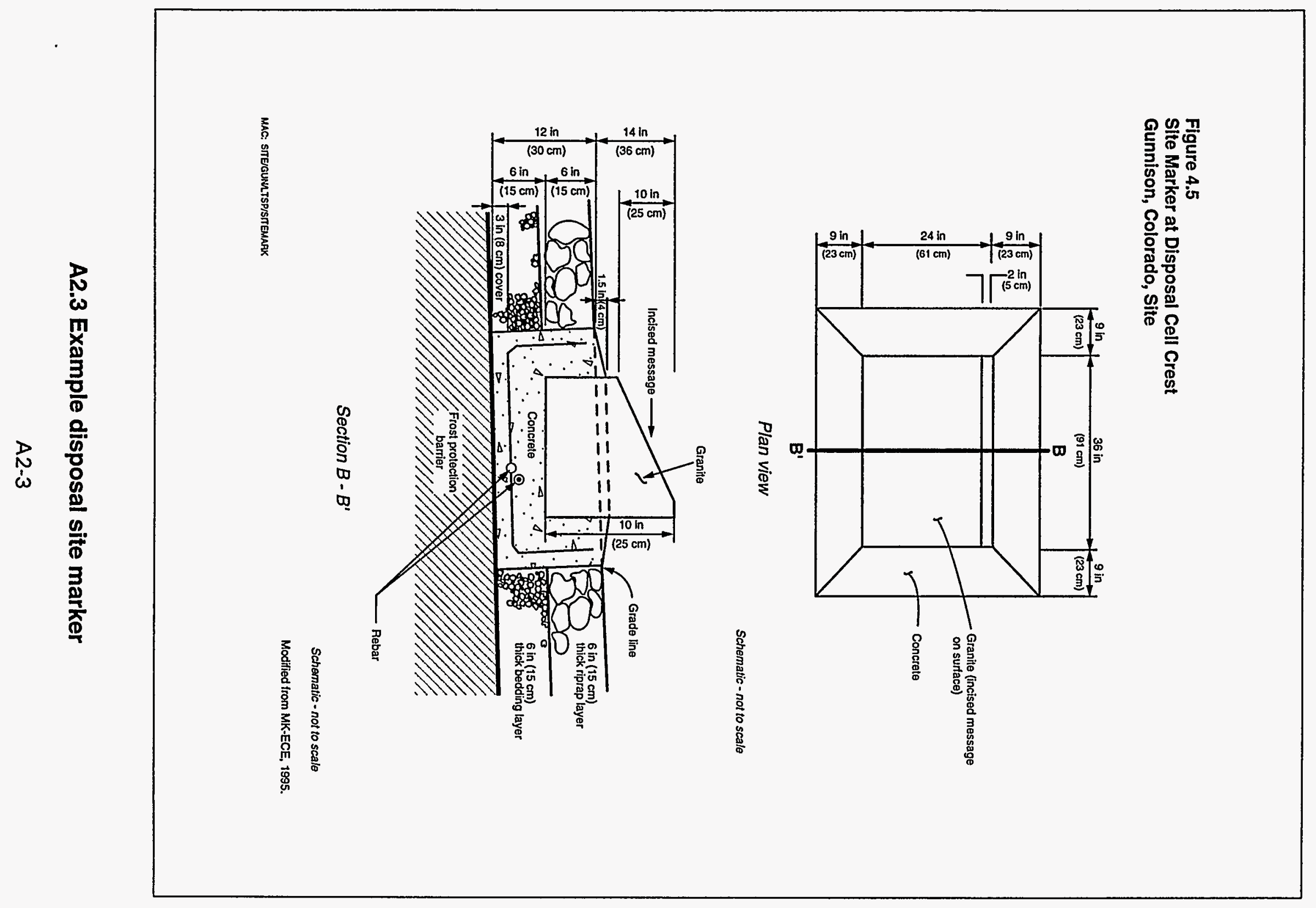




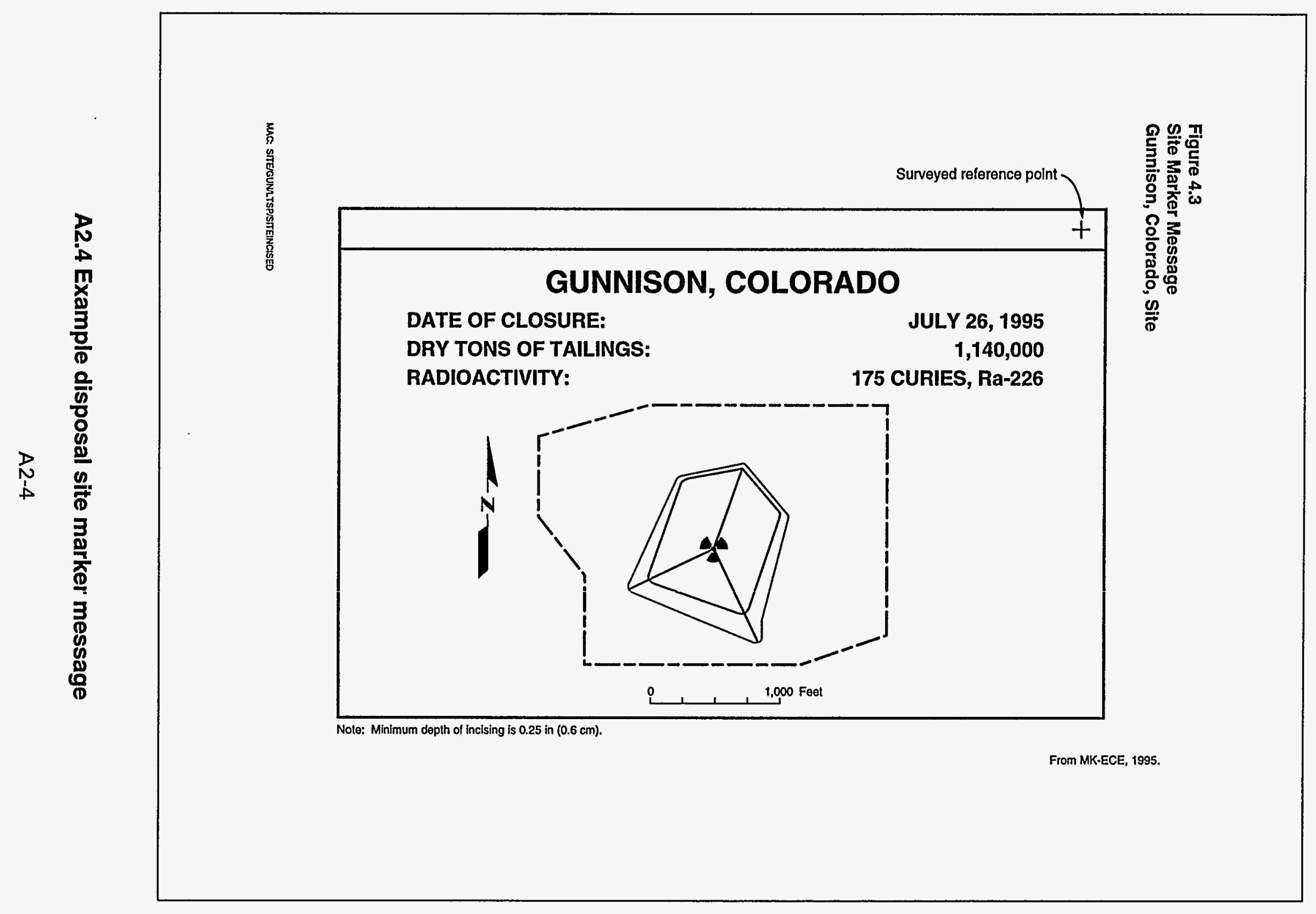




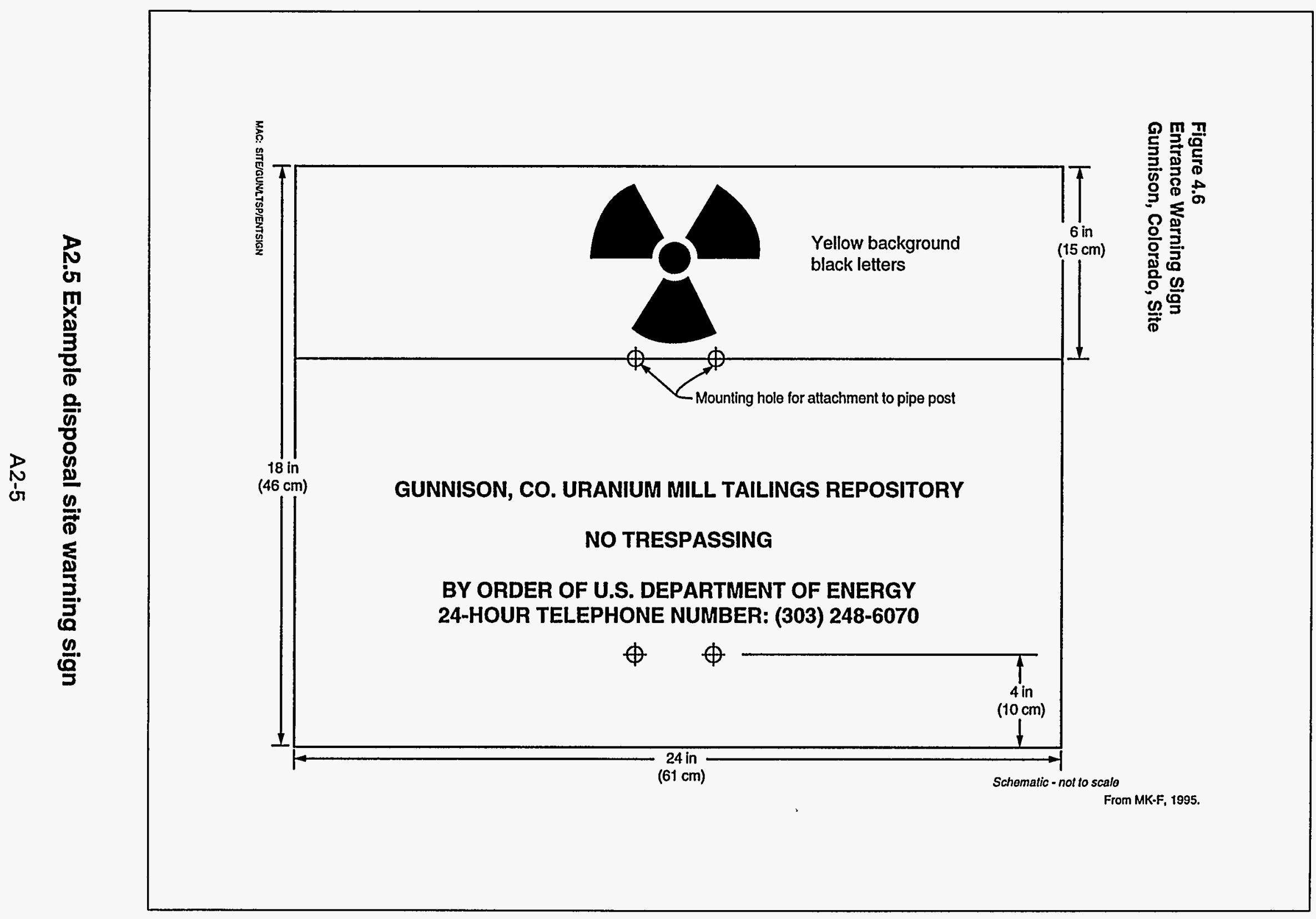


Table A2.1 Example locations of disposal site permanent surveillance features

\begin{tabular}{cc}
\hline Feature & Location Coordinates $^{\text {a }}$ \\
\hline Site Markers & N 14,678; E 12,600 \\
SMK-1 & N 15,539; E 12,974 \\
SMK-2 & N 15,002; E 14,326 \\
Survey/Boundary Monuments \\
\hline SM-1/BM-1 & N 16,648; E 14,321 \\
SM-2/BM-2 & N 16,663; E 12,500 \\
SM-3/BM-3 & \\
Boundary Monuments & N 16,394; E 11,660 \\
BM-4 & N 15,828; E 11,662 \\
BM-5 & N 15,343; E 11,996 \\
BM-6 & N 15,009; E 11,998 \\
BM-7 & N 14,685; E 11,999 \\
BM-8 & N 14,684; E 12,326 \\
BM-9 & N 14,679; E 13,632 \\
BM-10 & N 14,897; E 14,327 \\
BM-11 &
\end{tabular}

Background Well

GUN08-0716 N 17499; E 13,216

POC Wells

$\begin{array}{ll}\text { POC-1 } & \text { N } 15,500 ; E 12,375^{b} \\ \text { POC-2 } & \text { N } 16,125 ; E 12,625^{b} \\ \text { POC-3 } & \text { N } 16,375 ; E 13,250^{b} \\ \text { POC-4 } & \text { N } 15,750 ; E 13,675^{b} \\ \text { POC-5 } & \text { N } 15,500 ; E 13,500^{b} \\ \text { POC-6 } & \text { N } 15,000 ; E 13,375^{b}\end{array}$

${ }^{a}$ Coordinates in feet based on Project Survey Control

Point (N 15,000; E 15,000 - modified Colorado State

Plane Coordinate System).

${ }^{b}$ Estimated coordinates based on tentative well locations.

From MK-ECE, 1995. 
ATTACHMENT 3

SAMPLE INSPECTION CHECKLIST 



\section{SITE INSPECTION CHECKLIST FOR THE SITE NAME, STATE URANIUM MILL TAILINGS DISPOSAL SITE}

Date of Last Inspection:

Reason for Last Inspection:

Responsible Agency : DOE Grand Junction Projects Office

Address: P.O. Box 2567, Grand Junction, Colorado 81502-2567

Responsible Agency Official:

Inspection Start Date and Time:

Weather Conditions at Site:

Inspection Completion Date and Time:

Inspector:

$$
\text { Name }
$$

Title

Organization

Inspector:

$$
\text { Name }
$$

Title

Organization

Inspector:

$$
\text { Name }
$$

Title

Organization

\section{A. GENERAL INSTRUCTIONS}

1. All checklist items must be completed and comments made to document the results of the site inspection. The completed checklist is part of the field record of the inspection. Additional pages should be attached, as necessary.

2. Inspectors are to provide an up-to-date resume for inclusion in the inspection report.

3. Any checklist line item that is checked by an inspector must be explained or appropriately referenced. Explanations are to be placed on additional attachments and cross referenced. Sketches, measurements, and annotated site atlas overlays will be added if necessary.

4. The site inspection is a walking inspection of the entire site, including the perimeter and sufficient transects to inspect the entire surface and all features specifically described in this checklist. Every monument, site marker, sign, monitoring well, and erosion control marker will be inspected.

\footnotetext{
'Responsibility for site inspections assigned by DOE UMTRA Project Office, Albuquerque, to DOE Grand Junction Projects Office, 6 November 1990
} 
5. Monitoring volunteer plant growth and the need to control vegetation should take place during the site inspections. The species of plants and extent of plant coverage on the cell should be determined and documented in the site inspection reports.

6. A set of color print 35-mm photographs will be taken for comparison to baseline photographs and determine significant differences in site appearance. In addition, all anomalous features or new features (such as changes in adjacent area land use) must be photographed. A photo log will be made for each photograph taken. The photo log is part of this checklist.

7. Field notes in a bound book with numbered pages will be taken to assist in completion of this checklist will become part of the inspection record. No form is specified; the field notes must be legible and in sufficient detail to enable review by succeeding inspectors and the responsible agency.

B. PREPARATION (to be completed prior to site visit)

1. License reviewed (including Long-Term Surveillance and Maintenance Plan).

2. Site as-built plans reviewed and base map with copies of the following site atlas overlays obtained:

a. Adjacent off-site features and land use; fences, signs; access roads and paths.

b. Survey monuments, boundary markers, site markers, aerial photo ground controls, ground photo locations.

c. Monitor wells, site drainage, diversion channels.

d. Planned inspection transects and vegetation cover.

e. Other.

These overlays will be used to identify site features and record appropriate field data.

3. Previous inspection reports reviewed.

a. Were anomalies or trends in modifying processes detected on previous inspections?

b. Was custodial maintenance performed?

c. Was contingency repair work done as a result of the inspection? 
4. Site custodial maintenance and contingency repair

Yes No records reviewed.

a. Has site contingency repair resulted in a change from as-built conditions?

b. Are reviewed as-builts available that reflect contingency repair changes?

5. If required, adjacent property entry approval obtained (attach signed access agreement).

6. Aerial photos reviewed, if taken since last inspection. For each set, enter date taken, scale, and if interpreted. The following standard disposal site features are documented with photographs during every scheduled inspection:

- Permanent site surveillance features.

- Fences, gates, access roads, perimeter road, and paths.

- Drainage channel or other diversion channels.

- Trench drains.

- Ground water monitor wells and other monitoring locations.

- The disposal cell (top, sides, apron, and surrounding area). Panoramic sequences of photographs from selected vantage points may be used for this purpose.

- Any evidence of erosion (e.g., gullies, rills) the inspector considers significant and includes in the text of the inspection report.

- Off-site features that may affect the site in the future.

- Vegetation (site area, cover and volunteer plant growth).

- Erosion protection material (riprap).

- Potential problem areas. 
7. Examine aerial photographs to determine if they suggest any of the following. (If yes, give photo set date, location, and indicate if item noted by interpreter or inspector):

a. Human intrusion?

b. Animal intrusion?

c. Channelized erosion on slopes?

d. Change in area drainage?

e. Landslides?

f. Creep on slopes?

g. Obstruction of diversion channels?

h. Bank erosion of diversion channels?

i. Seepage?

j. Cracking?

k. Change in vegetative cover?

I. Displacement of fences, site markers, boundary markers, or monuments?

m. Change in adjacent land use?

n. Volunteer plant growth?

o. Evidence of tailings exposure or transport?

8. Examine as-builts or subsequent inspection reports, noting distance and azimuth from designated site location, such as a monument, to adjacent off-site features that eventually could affect site integrity.

Off-site feature Site monument no. Distance

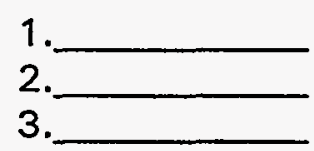


9. Assemble the following equipment, as needed, to conduct inspections:

a. Cameras, film, and miscellaneous support equipment.

b. Binoculars.

c. Tape measure.

d. Optical ranging device.

e. Brunton compass.

f. Photo scale stick.

g. Erasable board.

h. Plant press, plastic bags for vegetation.

I. Keys to locks.

j. Bolt cutters.

k. Hand lens.

I. Clipboard.

m. Bound, numbered field notebook.

n. Other.

\section{SITE INSPECTION}

1. Inspect adjacent off-site features (within 0.25 mile

[0.4 meter] of site boundary) for the following:

a. Changes in use of adjacent areas (grazing, construction, agriculture)?

b. New roads or trails?

c. Change in the position of nearby stream channels?

d. Headward erosion of nearby gullies?

e. New drainage channels?

f. Other?

2. Inspect access roads and paths, fences, gates, and signs for evidence of the following:

a. Break in the fence.

b. Damage to posts or weakened anchoring.

c. Erosion or digging beneath the fence.

d. Tampering or damage to the gate.

e. Human intrusion. 
f. Intrusion by large animals.

g. Damage to or removal of signs (number of signs replaced: ).

h. Road or access obstruction.

i. Excessive volunteer plant growth.

j. Other.

3. Examine monuments and other permanent features for evidence of the following:

a. Disturbances to survey or boundary monuments.

b. Disturbances to site markers by man or natural processes.

c. Threatened integrity of monument or site markers by natural processes.

d. Are monuments or other features hidden or covered by volunteer plant growth?

e. Other.

4. Examine the crest for evidence of the following:

a. Uneven settling (depressions, scarps).

b. Cracking.

c. A breach in the outer cover layer.

d. Erosion.

1) By water (rills, rivulets).

2) By wind (pedestal rocks, ripple marks).

e. Changes in the vegetation cover (not as described in the as-builts).

f. Animal burrowing? 
g. Volunteer plant growth.

h. Other.

5. Examine slopes for evidence of the following:

a. Downslope movement (creep, terraces, deflection of plants).

b. Cracking.

c. Depressions or bulges on the slope.

d. A breach in the outer cover layer.

e. Erosion.

1) By water.

2) By wind.

f. Channelized water runoff (rivulets, gullies).

g. Seepage (moisture, color, vegetation).

$h$. Significant changes in vegetation cover since the last inspection.

i. Animal burrowing.

j. Deterioration of riprap or gravel cover.

k. Volunteer plant growth.

I. Other.

6. Examine the periphery (within site boundaries) for evidence of the following:

a. Seepage, such as wet areas or localized change of vegetation.

b. Sediment transport from the tailings pile by water or wind. 
c. Changes in the vegetative cover (not as described in the as-builts).

d. Changes in drainage (not as described in the as-builts).

e. Volunteer plant growth.

f. Other.

7. Examine diversion channels for evidence of the following:

a. Bank erosion.

b. Disturbance of riprap structure by people or natural processes.

c. Channel erosion.

d. Sedimentation in the channel.

e. Any obstructions in the channel.

f. Diversion channels not functioning.

g. Volunteer plant growth.

h. Other.

8. Examine monitor wells for evidence of the following:

a. Disturbances by man or natural processes.

b. Potential threat to the integrity of any monitor well by natural processes.

c. Missing caps or locks.

d. Volunteer plant growth that covers or hides a well.

e. Other. 


\section{FIELD CONCLUSIONS}

1. Is there an imminent threat to the integrity of the

Yes $\quad \underline{\text { No }}$ tailings pile? (Immediate report required)

Person

Agency to whom report made:

2. Are more frequent inspections required?

3. Are existing contingency repair actions satisfactory?

4. Is a follow-up inspection required?

5. Is a contingency report or custodial maintenance required?

6. Is the rationale for field conclusions documented as the text of this report?

\section{E. SITE INSPECTION PHOTO LOG (Attached)}

\section{F. CERTIFICATION (when appropriate)}

I have conducted a prelicensing inspection of the Site Name, State, uranium mill tailings site in accordance with the procedures of the license (includes the site surveillance plan) as recorded on this checklist, attached sheets, field notes, photo log sheets, and photos.

Chief Inspector's Signature

Title

(Stamp or Seal)
Printed Name

Date 
Page ___ of

EXAMPLE SITE INSPECTION PHOTO LOG

Site: Site Activity:

Date: Time of Day: From to

Weather Conditions:

Roll Number:

Film Type: Number of Exposures:

Photo Number

\section{Location and Direction}

Description 
Page __ of

\section{EXAMPLE SITE INSPECTION PHOTO LOG (CONT.)}

\section{Site}

Date

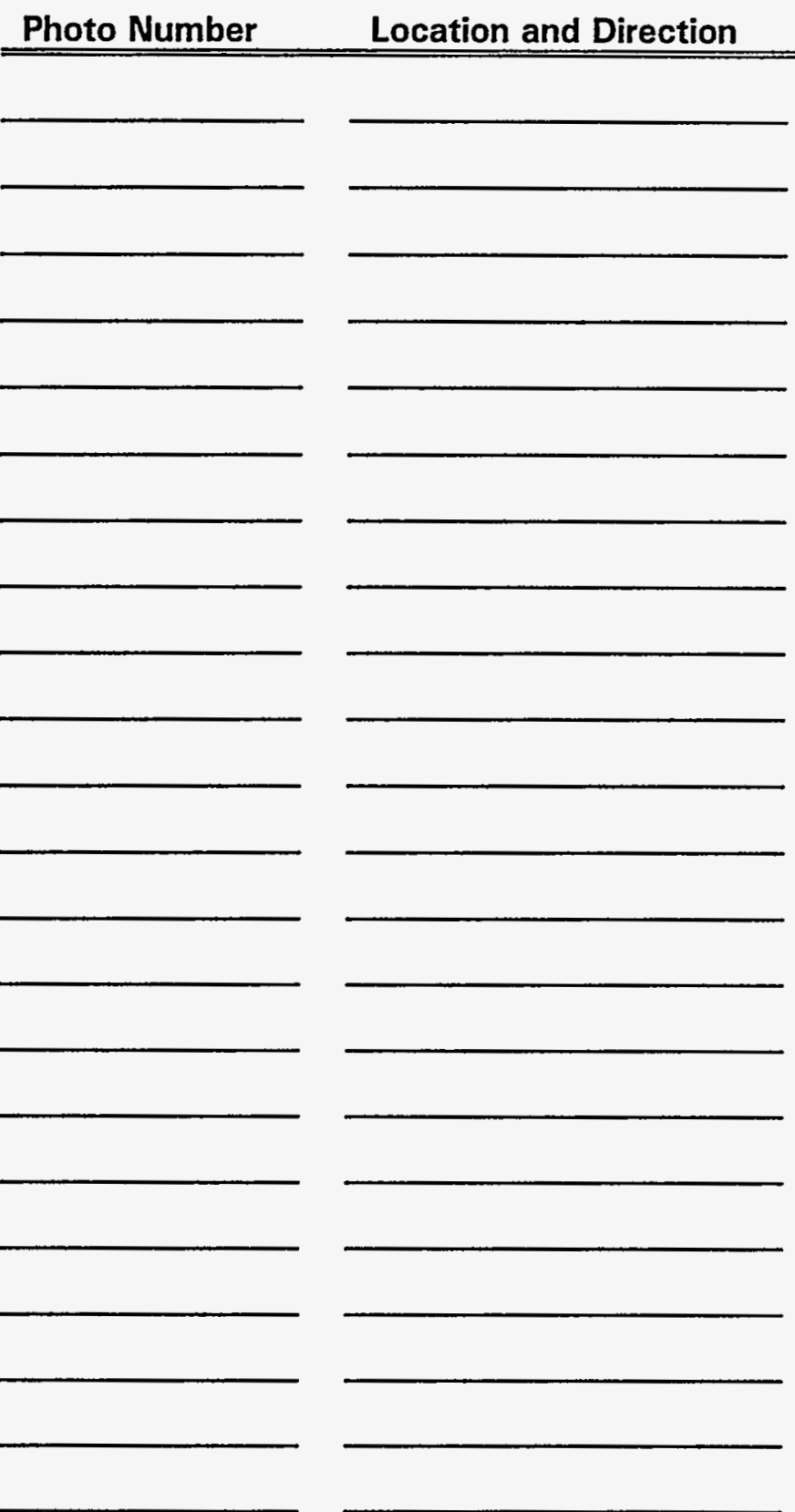

\section{Photographer:}

\section{Printed Name}

\section{Description}

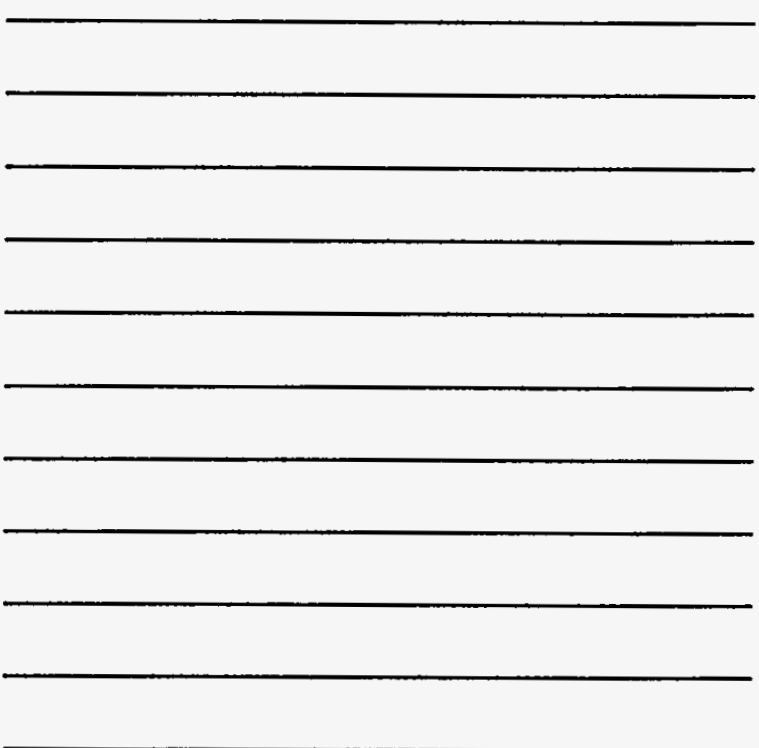




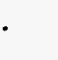


ATTACHMENT 4

DISPOSAL SITE AND DISPOSAL CELL INSPECTION TECHNIQUES 


\section{DISPOSAL SITE AND DISPOSAL CELL INSPECTION TECHNIQUES}

An effective way to initiate inspection of the disposal site area and disposal cell is with a series of well-planned traverses around the perimeter of the disposal site, and along the base, sideslopes, and crest of the disposal cell and diversion channels. The number of traverses along the sideslopes is determined by the height of the disposal cell. Sideslope traverses generally should be spaced at 50-yard (46-meter [m]) intervals. Traverses across the disposal cell crest should be diagonal to its long axis. At a minimum, the site perimeter and site area traverses should be selected to observe damage or disturbance to the following features:

- Site perimeter roads.

- Fences, gates, and locks.

- Permanent site-surveillance features.

- Ground water monitor wells and other monitoring points.

- Other instrumentation or surveillance features.

- Site area vegetation or volunteer plant growth.

- Sedimentation or erosion.

- Lateral stream cutting or channel migration.

Traverses along the engineered component (diversion ditches, cell sideslopes, cell crest, and cover) should be walked along their complete length and examined for evidence of the following:

- Structural instability caused by differential settlement, subsidence, cracking, sliding, or creep.

- Erosion evidenced by the development of rills or gullies.

- Sedimentation or debris.

- Rapid deterioration of rock caused by weathering or erosion.

- Removal of rock or other disposal cell material.

- Seepage.

- Intrusion (inadvertent or deliberate) by humans or animals (burrowing).

- Vandalism. 
- Development of trails from human or animal activity.

- Volunteer plant growth, especially on the disposal cell or in the diversion channels.

- Erosion of vegetation if the site area or disposal cell cover is vegetated.

Modifications due to natural processes are most likely to occur on the lower portion of the sideslopes of the disposal cell. These modifications include gullying and headward erosion, cracking, landslides, creep, piping, sheet erosion, sedimentation or deflation, animal and plant intrusion, and extreme natural events (e.g., tornadoes or earthquakes). The site inspectors should know how to recognize, quantify, and record these processes for future evaluation. If any modifying features are observed during the inspection, the following data should be recorded briefly on the inspection checklist and fully discussed in the inspection report:

- Extent of area affected, stability, and nature of movement (e.g., planar or rotational).

- Number of features, spacing, length, depth, and width.

- Related erosional features.

- Patterns of occurrence.

- Species present (if plants or animals are found on the site).

- Location and density of volunteer plant growth.

Inadvertent or casual intrusion by humans or animals is not of great concern, but evidence of removal of the cover, extensive vandalism to signs and monuments, or the presence of well-established trails should be described in detail. Continuing vandalism may require more active measures to control access to the site.

If new conditions requiring continuing observation, monitoring, or immediate action are discovered during the inspection, a description of the problem and recommended follow-up actions, if required, should be included in the inspection report.

Some disposal cells have vegetated rather than rock covers. A plant specialist should participate in the inspection if circumstances warrant. If timing of the inspection conflicts with the overall schedule for other site inspections, a plant specialist or other qualified person may conduct a separate inspection at a more optimum time of year. The condition of expected plant growth could affect the timing of the aerial photography. The areas around the disposal cells are recontoured and seeded at the end of remedial action. The LTSP discusses the seed mix needed to revegetate the recontoured area.

At disposal cells with rock covers, volunteer plant growth may be observed during the inspection. If an unknown plant species is encountered by a qualified inspection team member, biologists from the Soil Conservation Service or Bureau of Land Management or 
botanists from a local college or university could be contacted. Also, samples of the plant species in question may be collected and taken into the office for identification.

The inspection team's determination of plant density on the disposal cell likely will be subjective. The inspection team should determine if there are areas of moderate-to-dense vegetation growth on the disposal cell. At the Shiprock disposal cell, coverage of 10 to 25 plants per 100 square feet $\left(\mathrm{ft}^{2}\right)\left(9\right.$ square meter $\left.\left[\mathrm{m}^{2}\right]\right)$ is considered moderate and coverage of more than 25 plants per $100 \mathrm{ft}^{2}\left(9 \mathrm{~m}^{2}\right)$ is considered densely vegetated (DOE, 1992). If moderately to densely vegetated areas are noted, further study may be warranted.

The need for further study also is dictated by site conditions. For example, if there is a $7 \mathrm{ft}(2 \mathrm{~m})$ frost protection layer above the infiltration/radon barrier and the plant species growing on the disposal cell likely would not grow that deep, further investigation may not be warranted. However, if there is 1 to $3 \mathrm{ft}(0.3$ to $1 \mathrm{~m})$ of cover above the infiltration/radon barrier layer, further study may be required. Further study could include a more detailed analysis of the rooting patterns of the species in question based on an analysis of existing information.

The concept of using the ratio of rooting depth to shoot height to determine the rooting depth of species observed in the field is discussed in the disposal cell cover biointrusion sensitivity assessment (DOE, 1995). This report provides the rooting depth to shoot height for some common species observed on the disposal cells. This ratio used with knowledge of the cover characteristics may help field inspectors determine if vegetation control measures are required. This ratio should be used with caution to determine site-specific vegetation control measures because rooting depth for some of the common species growing on the disposal cells may be density-dependent. Vegetation control measures based on the root-to-shoot ratio should be determined by individuals familiar with this concept and its limitations.

Field studies show that plant growth on some rock disposal cells is sparse (e.g., the Green River and Clive, Utah, cells) while plant growth on other rock-covered cells is more extensive (e.g., Shiprock, New Mexico; Burrell, Pennsylvania; and Cheney, Colorado). These studies also show that plant roots have grown into the infiltration/radon barrier layer at some of the disposal cells (DOE, 1992; Burt, 1995). The impacts of plant root growth into this layer have not been determined although studies on the UMTRA Project and elsewhere indicate that such plant root growth could result in an increase in radon emanation from the disposal cell (DOE, 1995; Morris and Fraley, 1989). Other potential impacts from plant biointrusion into the disposal cell include increased water infiltration into the cell, breakdown of the engineered cover system, and transport of other contaminants out of the cell.

Because the rooting patterns of a given plant species may vary with ecological conditions and from species to species, the analysis of plant growth on the cells must be addressed on a site-by-site basis. A species that altered its rooting pattern based on varying conditions is the summer cypress at the Cheney disposal cell. A 4.5-ft $(1.4-\mathrm{m})$ tall summer cypress was excavated from a sparsely vegetated area (plants at least $10 \mathrm{ft}[3 \mathrm{~m}$ ] apart); its rooting depth was 14 inches $(36$ centimeters $[\mathrm{cm}])$. A 32 -inch $(81 \mathrm{~cm})$ tall 
summer cypress excavated in a densely vegetated area had extended roots 25 inches (64 $\mathrm{cm}$ ) into the cover (the depth of the excavation); small roots continued down into the cover for an additional undetermined depth (Burt, 1995). The rooting depth-to-shoot height ratio of summer cypress was determined to be 1 to 1 although rooting depth can be highly variable (DOE, 1995). The summer cypress from the sparsely vegetated area had a root depth-to-shoot height ratio of 0.3 to 1 while this same ratio in the densely vegetated area was probably about 1 to 1 . Although in this example a root-to-shoot ratio of 1 to 1 would be conservative, data indicate that rooting depth appears to increase with plant density. 
REFERENCES

Burt, C., 1995. Jacobs Engineering Group Inc., personal communication with S. Cox, Jacobs Engineering Group Inc., UPDCC File Location No. 5.15.1.1, Albuquerque, New Mexico, 5 October 1995.

DOE (U.S. Department of Energy), 1995. UMTRA Project Disposal Cell Cover Biointrusion Sensitivity Assessment, DOE/AL/62350-200, Rev. 1, prepared for the U.S. Department of Energy, Environmental Restoration Division, UMTRA Project Team, Albuquerque, New Mexico.

DOE (U.S. Department of Energy), 1992. Vegetation Growth Patterns on Six RockCovered UMTRA Project Disposal Cells, DOE/AL-400677.0000, prepared for the U.S. Department of Energy, UMTRA Project Office, Albuquerque Operations Office, Albuquerque, New Mexico.

Morris, R. C., and L. Fraley Jr., 1989. "Effects of Vegetation, a Clay Cap and Environmental Variables on Rn-222 Fluence Rate From Reclaimed Mill Tailings," Health Physics, Vol. 56, pp. 431-440. 

ATTACHMENT 5

EARTHQUAKE REPORTING CRITERIA 


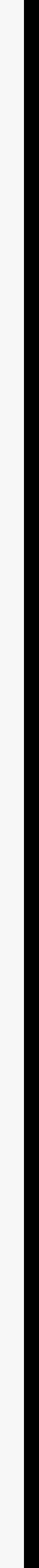




\section{LIST OF ACRONYMS}

\section{Acronym Definition}

DOE

U.S. Department of Energy

NEIC National Earthquake Information Center

UMTRA Uranium Mill Tailings Remedial Action

USGS U.S. Geological Survey 



\section{EARTHQUAKE REPORTING CRITERIA}

The U.S. Geological Survey (USGS) National Earthquake Information Center (NEIC) will notify the U.S. Department of Energy (DOE) when an earthquake of a specified magnitude is reported within a specified radius of a Uranium Mill Tailings Remedial Action (UMTRA) Project disposal site.

In determining a specific magnitude of earthquake or a site radial distance significant to a specific site, the following limitations of these parameters should be understood:

- Ground conditions resulting from severe weather (such as recent heavy rains) may cause variations in ground response at the site.

- The accuracy of the distance and attenuation relationships may vary due to local structure and stratigraphy.

- The accuracy of the reported magnitude and epicentral distance depends on the number and proximity of the reporting seismic stations, and quality of the data.

- The significance of regional earthquakes may depend on the orientation of the structure associated with an earthquake relative to the site. An earthquake on a fault that trends near the disposal site has implications for possible focusing of the ground response and migration of future aftershocks closer to the site.

The variability of the potential ground response and the need to review the significance of regional earthquakes relative to known or unknown structures suggest the minimum acceleration of 0.10 gravitational acceleration for long-term and short-term design should be used to define the significant radial distance from the site for a seismic event notification. The distance acceleration relationship of Campbell (1981) is recommended in the technical approach document (DOE, 1989) for the western United States, and the relationship applicable to the central United States is taken from Nuttli and Hermann (1978).

Figure A5.1 identifies the radius relative to the magnitude of earthquakes that would trigger the NEIC notification process to DOE. These radii and magnitudes are applicable to all disposal sites, regardless of seismic design of specific sites. Table A5.1 provides the design magnitude and peak acceleration for each site used to develop the notification criteria identified in Figure A5.1. 


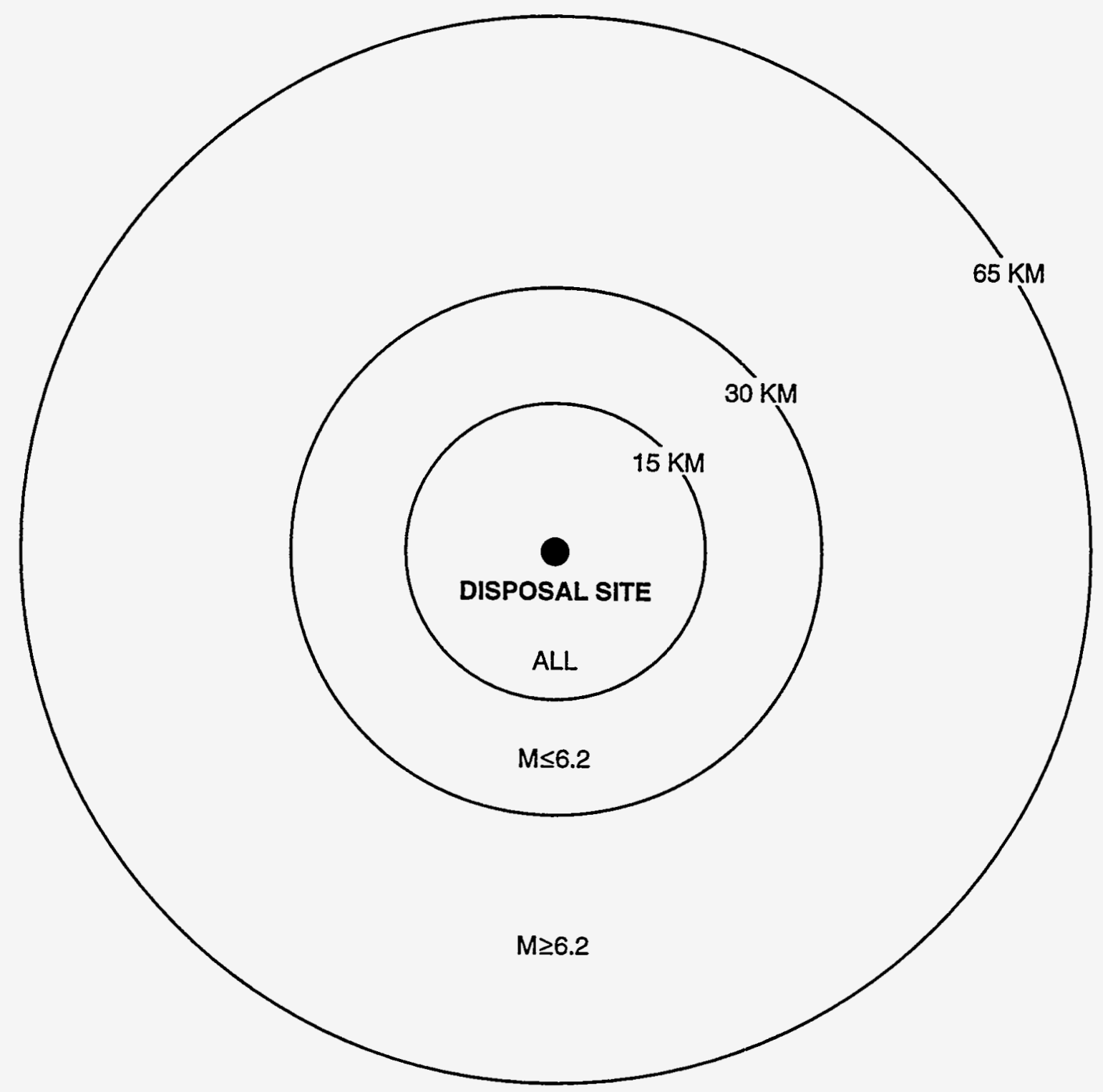

$$
\begin{array}{cc}
\text { DISTANCE } & \text { MAGNITUDE } \\
\hline 0.15 \mathrm{KM} & \text { ALL (DETECTABLE) } \\
0.30 \mathrm{KM} & 6.2 \text { OR LESS } \\
0.65 \mathrm{KM} & 6.2 \text { OR GREATER }
\end{array}
$$

FIGURE A5.1 
Table A5.1 Earthquake data for the UMTRA Project disposal sites

\begin{tabular}{|c|c|c|c|c|}
\hline Disposal site & Latitude & Longitude & $\begin{array}{c}\text { Design } \\
\text { earthquake } \\
\left(M_{L}\right)\end{array}$ & $\begin{array}{c}\text { Peak } \\
\text { acceleration } \\
\text { (g) }\end{array}$ \\
\hline $\begin{array}{l}\text { ARIZONA } \\
\text { Tuba City }\end{array}$ & N36.15 & W111.10 & 6.2 & 0.21 \\
\hline $\begin{array}{l}\text { COLORADO } \\
\text { Durango (Bodo Canyon) } \\
\text { Grand Junction (Cheney) } \\
\text { Gunnison (Landfill) } \\
\text { Maybell } \\
\text { Naturita (Dry Flats) } \\
\text { Rifle (Estes Gulch) } \\
\text { Slick Rock (Burro } \\
\text { Canyon) }\end{array}$ & $\begin{array}{l}\text { N37.15 } \\
\text { N38.91 } \\
\text { N38.51 } \\
\text { N40.55 } \\
\text { N38.21 } \\
\text { N39.60 }\end{array}$ & $\begin{array}{l}\text { W107.90 } \\
\text { W108.32 } \\
\text { W106.85 } \\
\text { W107.99 } \\
\text { W108.60 } \\
\text { W107.82 }\end{array}$ & $\begin{array}{l}a \\
6.0 \\
6.2 \\
6.2 \\
7.1 \\
6.2\end{array}$ & $\begin{array}{l}0.16 \\
0.34 \\
0.21 \\
0.21 \\
0.25 \\
0.21\end{array}$ \\
\hline $\begin{array}{l}\text { IDAHO } \\
\text { Lowman }\end{array}$ & $N 44.16$ & W115.61 & 7.0 & 0.34 \\
\hline $\begin{array}{l}\text { NEW MEXICO } \\
\text { Ambrosia Lake } \\
\text { Shiprock }\end{array}$ & $\begin{array}{l}\text { N35.41 } \\
\text { N36.80 }\end{array}$ & $\begin{array}{l}\text { W107.80 } \\
\text { W108.65 }\end{array}$ & $\begin{array}{l}6.2 \\
5.75\end{array}$ & $\begin{array}{l}0.21 \\
0.13\end{array}$ \\
\hline $\begin{array}{l}\text { NORTH DAKOTA } \\
\text { Bowman }\end{array}$ & $N 46.23$ & W103.55 & 6.0 & 0.15 \\
\hline $\begin{array}{l}\text { OREGON } \\
\text { Lakeview (Collins Ranch) }\end{array}$ & N42.2 & W120.3 & 7.5 & 0.52 \\
\hline $\begin{array}{l}\text { PENNSYLVANIA } \\
\text { Canonsburg } \\
\text { Burrell VP }\end{array}$ & $\begin{array}{l}N 40.26 \\
N 40.62\end{array}$ & $\begin{array}{l}\text { W80.25 } \\
\text { W79.65 }\end{array}$ & $\begin{array}{l}\mathrm{a} \\
\mathrm{a}\end{array}$ & $\begin{array}{l}0.10 \\
0.10\end{array}$ \\
\hline $\begin{array}{l}\text { TEXAS } \\
\text { Falls City }\end{array}$ & N28.91 & W98.13 & & 0.10 \\
\hline $\begin{array}{l}\text { UTAH } \\
\text { Green River } \\
\text { Mexican Hat } \\
\text { Salt Lake City (Clive) }\end{array}$ & $\begin{array}{l}\text { N39.0 } \\
\text { N37.10 } \\
\text { N40.69 }\end{array}$ & $\begin{array}{l}W 110.1 \\
W 109.85 \\
W 113.11\end{array}$ & $\begin{array}{l}6.2 \\
6.2 \\
7.1\end{array}$ & $\begin{array}{l}0.21 \\
0.21 \\
0.31\end{array}$ \\
\hline $\begin{array}{l}\text { WYOMING } \\
\text { Spook }\end{array}$ & N43.23 & W105.63 & 6.2 & 0.21 \\
\hline
\end{tabular}

${ }^{a}$ The seismic design for the Canonsburg, Burrell, and Durango disposal sites was based on a probabilistic approach of potential acceleration and did not assign a design magnitude.

Notes: 1 . The specific locations of the disposal cells are in parentheses.

2. The Belfield and Monument Valley tailings are codisposed at the Bowman and Mexican Hat sites, respectively.

3. The Riverton tailings were removed to a Title II site in Wyoming.

VP - vicinity property.

g-gravitational acceleration 32.2 feet per second per second.

$M_{L}$ - local magnitude. 


\section{REFERENCES}

Campbell, K. W., 1981. "Near-Source Attenuation of Peak Horizontal Acceleration," Bulletin of the Seismological Society of America, Vol. 71, pp. 2039-2070.

DOE (U.S. Department of Energy), 1989. Technical Approach Document, UMTRADOE/AL-050425.0002, DOE UMTRA Project Office, Albuquerque Operations Office, Albuquerque, New Mexico.

Nuttli, O. W., and R. B. Hermann, 1978. "State-of-the-Art for Assessing Earthquake Hazards, Report 12, Credible Earthquakes for the Central United States: U.S. Army Engineer Waterways Experiment Station," Miscellaneous Paper S-73-1, Report 12. 